\title{
National Laws and Contract Interpretation
}

It is not simple naivety, but a gross misunderstanding, to assume that national laws govern contract interpretation identically or in a substantially similar way. The need to determine the parties' joint intent, i.e., the common purpose of an interpretative exercise, does not automatically equate with the ways national law offers to achieve this aim. Nor does it automatically ensure similar results.

The proposition that national laws govern contract interpretation differently triggers two circular suggestions. On the one hand, the proposition follows a broader appreciation that the totality of contract law shapes contract interpretation via fundamental values, prevailing principles and other noninterpretative doctrines. This understanding of contract interpretation, as a product of the overall regulation of contract law, is well illustrated by those countries, such as Denmark or Norway, which, while having statutory regulation for contracts, do not have a formal enumeration of all general rules applicable to contract interpretation and where interpretation primarily develops through judicial guidance. ${ }^{1}$ On the other hand, the rules on contract interpretation themselves are focal for understanding the contract law's differences. They are an 'acid test of comparative law'2 that helps appreciate the peculiarity of a given state's contract law. For instance, it is the existing differences in approaches towards contract interpretation that mark certain contract laws as being more attractive for commercial transactions, such as English law, ${ }^{3}$ or ones that are more attractive for protecting weaker parties, such as Danish, Norwegian or Swedish laws. ${ }^{4}$ In other words, the contract laws of various states

1 See, for instance, Ruth Nielsen, Contract Law in Denmark (DJøF Publishing/Wolters Kluwer Law \& Business 2011) 150-152.

2 Filippo Viglione, 'Good Faith and Reasonableness in Contract Interpretation: A Comparative Perspective' (2009) 20 European Business Law Review 835, 835 .

3 English law has a well-known history of application in international commerce, be that regarding the sale of soft commodities, international financial transactions, mergers and acquisitions or other transactions. Reliance on the words of the contract ensures predictability in contract interpretation and serves as an important factor for the choice of English law for international commercial transactions. For the attractiveness of this interpretative approach for commercial transactions, referred to as the minimalist approach, see Jonathan Morgan, Contract Law Minimalism: A Formalist Restatement of Commercial Contract Law (Cambridge University Press 2013) 183.

4 Nordic laws are known for the far reach of good faith in correcting contractual imbalances, albeit somewhat limited in commercial context. See, Ole Lando, Marie-Louise

(C) YULIYA CHERNYKH, 2022 | DOI:10.1163/9789004414709_004

This is an open access chapter distributed under the terms of the CC BY-NC-ND 4. 0 licemsê. 9 rnykh - 9789004414709 Downloaded from Brill. come4/26/2023 10:07:11AM 
are distinct, and so is contract interpretation. Vice versa, contract laws vary because contract interpretation differs from one country to another.

Instead of investigating de novo all the differences of contract interpretation to varying degrees of magnitude, this chapter aims to provide an overview of some critical markers of similarities and dissimilarities in the regulation of contract interpretation across various national laws. The chapter proceeds by firstly analysing the contribution of comparative scholarship to the existing body of knowledge and then by cataloguing selected similarities and differences of contract interpretation across jurisdictions.

\subsection{What Do We Know: Comparative Scholarship}

A general observation that various laws might have different regimes for contract interpretation does not raise much complexity or imagination. Nor is it counterintuitive. Laws do differ across jurisdiction. And if contract formation, contract performance, contract termination or contract validity all might be subject to different regulation, there is nothing extraordinary in the proposition that contract interpretation may differ as well. Nevertheless, investigation of precisely how different the laws are with regard to contract interpretation constitutes an extremely demanding exercise.

The complexity of the precise understanding of differences in contract interpretation under national laws is manifold. Difficulties pertain to the overall number of laws, the fact that many of them have not been translated, dominant mono-national focus in scholarship on contract interpretation, as well as complexities associated with contract interpretation as an object of comparison. Indeed, the existence of roughly 200 countries, some of which have quite distinct regulations on contract interpretation, even within their constituent parts, ${ }^{5}$ represents an objective challenge for an all-encompassing meaningful

Holle and others (eds), Restatement of Nordic Contract Law (DJøF Publishing) 167-195; Boel Flodgren and Eric M Runesson, Contract Law in Sweden (Kluwer Law International 2015) 94-101; Kåre Lilleholt, 'Application of General Principles in Private Law in the Nordic Countries' (2013) 20 Juridica International 12. Unsurprisingly, the initiatives to promote the choice of Nordic law for international transactions emphasise some other arguments, but not approaches to contract interpretation as such. For instance, Swedish contract law is presented as a neutral choice primarily for parties from common and civil law countries who wish to choose neither of them - see Boel Flodgren, Eric M Runesson and Björn Riese, 'Retten som konkurrensmedel' (2016/2017) 2 Juridisk Tidskrift 295.

5 Distinctions in approaches towards contract interpretation in the UK and the USA are classic examples - see Darius Palia and Robert E Scott, 'Ex Ante Choice of Jury Waiver Clauses in Mergers' (2015) 17 American Law and Economics Review 566, 571-572; Gregory Klass, 
comparison. Academic work on contract interpretation progress rather independently in many of these jurisdictions without being engaged in comparative exercises. While some publications, especially with regard to laws that are frequently applied in international transactions are either originally written in English or translated into it, ${ }^{6}$ those laws that are less exposed to global application in international transactions are addressed mostly in national languages. ${ }^{7}$

'Contract Law in the United States' in Jacques H Herbots and others (eds), International Encyclopaedia Contracts (2nd edn, Kluwer Law International 2012) 142-151; Edward Allan Farnsworth, Contracts (2nd edn, Little, Brown and Company 199o) 463-559; Ahmet Cemil Yildirim, Interpretation of Contracts in Comparative and Uniform Law (Kluwer Law International 2019) 108-124; Scottish Law Commission, 'Report on Review of Contract Law: Formation, Interpretation, Remedies for Breach, and Penalty Clauses' (scOT LAW COM No 252, SG/2018/34, March 2018) 94-97, available at <http://www.scotlawcom.gov.uk/ files/1115/2222/5222/Report_on_Review_of_Contract_Law_ -_Formation_Interpretation_ Remedies_for_Breach_and_Penalty_Clauses_Report_No_252.pdf> accessed 25June 2021.

6 The White \& Case and Queen Mary University survey in 2010 revealed the following to be among the most used substantive laws in international transactions: English law (40\%), New York law (17\%), Swiss law (8\%), French law (6\%) and US law where the respondents did not specify the state $(5 \%)$, other laws as a residual category and including German, Australian and Californian (24\%) - see White \& Case and Queen Mary, University of London, '2010 International Arbitration Survey: Choices in International Arbitration' (2010) <http://www.arbitration.qmul.ac.uk/research/2010/> accessed 25 June 2021. On contract interpretation under English law, law of New York, Swiss law, French law, German law and Australian law in the English language see, for instance, Andrew Burrows, A Restatement of the English Law of Contract (Oxford University Press 2016) 8095; Catherine Mitchell, Interpretation of Contracts (2nd edn, Routledge 2019); Lord Justice Lewison, The Interpretation of Contracts (6th edn, Sweet \& Maxwell 2017); John Cartwright, Contract Law: An Introduction to the English Law of Contract for the Civil Lawyer (3rd edn, Hart Publishing 2016) 202-210; Glen Banks and Judith S Kaye, New York Contract Law: A Guide for Non-New York Attorneys (New York State Bar Association 2015) 149-189; Eugen Bucher, 'Law of Contracts' in François Dessemontet and Tuğrul Ansay (eds), Introduction to Swiss Law (3rd edn, Kluwer Law International 2004) 112-115; Simon Whittaker, 'Contract, Contract Law and Contractual Principle' in John Cartwright and Simon Whittaker (eds), The Code Napoléon Rewritten: French Contract Law after the 2016 Reforms (Hart Publishing 2017) 29, 43-54; Gerhard Dannemann, An Introduction to German Civil and Commercial Law (British Institute of International and Comparative Law 1993) 11-37; Basil S Markesinis and others, The German Law of Contract: A Comparative Treatise (2nd edn, Hart Publishing 2006) 119-143; Lord Justice Lewison and David Hughes, The Interpretation of Contracts in Australia (Thomson Reuters 2011).

7 For instance, contract law, more generally, and contract interpretation in particular, in countries such as Belarus, the Russian Federation or Ukraine remains unknown to a larger audience, with publications mostly in Russian, Belarussian and Ukrainian - see Василий Владимирович Витрянский и Михаил Исаакович Брагинский, Договорное Право: Общие Положения, Кн. 1 (3-е изд, Статут 2009) [Vasily Vladimirovich Vitryansky and Mikhail Isaakovich Braginsky, Contract Law: General Provisions (Book1, 3rd edn, Statute 20о9)]; Валерий Николаевич Годунов, 'Гражданско-правовой договор и сфера его применения' (2004) 9 Право в Современном белорусском обществе, 301-312 [Valery 
The lack of translations of the regulation and works on contract interpretation in English as the lingua franca of modern academia leaves comparison for international scholars a complicated endeavour. Above all, the most important challenge lies not so much in the number of different laws, or the necessity of their translation, or accessibility of scholarship focused on national laws' regulation in the field of contract interpretation, but in the rules and regulations that are to be compared. Being inseparable from legal reasoning and legal method, contract interpretation cannot be understood meaningfully through static comparison of the existent rules and regulations. Only dynamic comparison of the law in operation would bring a proper understanding of contract interpretation. Such comparison requires a deep understanding of the operation of the legal rules in the jurisdiction in question. Despite all the complexities, it is still fair to say that comparative studies inform our understanding of how differently national laws approach contract interpretation.

To overcome the challenge pertaining to the object of comparison, some of these studies employ a functional method. Concentrating on how interpretative rules operate, ${ }^{8}$ the method permits not only the addressing of the

Nikolaevich Godunov, 'Civil Law Contract and the Sphere of its Application' (2004) 9 Law in the Modern Belarusian Society 301-312]; Олександр Васильович Дзера та інші, (ред.), Науково-практичний коментар Цивільного кодексу Украйни, 1 т. (5-е вид., Юрінком Інтер 2013) 363-364 [Dzera O.V. and others (eds), Scientific and Practical Commentary to the Civil Code of Ukraine (5edn, 1 volume, Yurinkom Inter 2013, 301-312]; Наталья Вацлавовна Степанюк, Толкование гражданско-правового договора: проблемь теории и практики (НИЦ ИНФРА-М 2013) 25 [Natalia Vatslavovna Stepanyuk, Interpretation of Civil Contracts: Problems of Theory and Practice (Scientific-Research Center INFRA-M 2013) 25]. At the same time, one has to acknowledge some academic initiatives to enhance the information on the contract laws of various states in English. One of the most complete book projects currently covers 46 jurisdictions in national monographs - see Jacques H Herbots (ed), International Encyclopaedia for Contracts (Wolters Kluwer) <www.kluwerlawonline.com/toc.php?pubcode=CONT > accessed 25 June 2021.

8 The Cornell project of Professor Schlesinger and Sacco's theory of legal formants shaped the functional method. On Schlesinger's approach to comparison, see Rudolf Schlesinger, 'The Common Core of Legal Systems - And Emerging Subject of Comparative Studies' in Kurt H Nadelmann, Arthur T von Mehren and John N Hazard (eds), Legal Essays in Honor of Hessel E. Yntema (A. W. Sijthoff 1961) 65. On Sacco's theory of legal formants, see Rodolfo Sacco, 'Legal Formants: A Dynamic Approach to Comparative Law' (1991) 39 American Journal of Comparative Law 1, 34. The functional method, as applied by R. Schlesinger, has influenced other comparatists. For instance, the project of the Common Core of European Private Law has expressly acknowledged Schlesinger's method as 'the cultural heritage of anyone who claims to engage in comparative law' and as 'the cultural DNA' of each participant in the project - see the official page for the Common Core of European Private Law - Mauro Bussani and Ugo Mattei, 'Common Core of European Private Law' <http:// www.jus.unitn.it/dsg/common-core/approach.html\# $3>$ accessed 25 June 2021. For a comprehensive observation on functional method(s) in comparative law, including existing 
apparent differences in contract interpretation, but, importantly, tackling of different interpretative rules leading to the same results, because of the operation of other non-interpretative doctrines or, vice versa, to identifying the relevance of other non-interpretative doctrines that, in the presence of similar interpretative rules, lead to different results. ${ }^{9}$ The core of the method represents observations and comparison of the application of legal rules to concrete situations described in neutral terms. An exclusion of legal terms in descriptions with a preference for a factual - and to the extent possible - non-legal description, contributes to the required neutrality and diminishes misunderstanding that follows from a different meaning attributed to the same or similar legal concepts under various laws. The studies informed by the method give a more nuanced and differentiated answer to a false assumption on the similarities of contract interpretation across laws or different legal systems because of the similarities of the results..$^{10}$ At the same time, the method is not blind

criticism, see Ralf Michaels, 'The Functional Method of Comparative Law' in Mathias Reimann and Reinhard Zimmermann (eds), The Oxford Handbook of Comparative Law (Oxford University Press 2006) 340-380.

9 The point may be illustrated by the example used by Giuditta Cordero-Moss on the transfer of activity between two doctors (medical firms), who failed to agree to anticompetitive provisions in their contract on activity swapping. The case not only demonstrates differences between the laws in addressing a gap in a contract (German and Norwegian laws), but also that the same results were obtained through different interpretative rules and doctrines (Italian and English law) - see Giuditta Cordero-Moss, 'Lectures on Comparative Law of Contracts' (2004) 166 Publications Series of the Institute of Private Law, University of Oslo 89, 93-98.

10 The works applying functional method elucidate numerous distinctions in areas that might create an illusion of uniform perception. For the examples of the different treatments of boilerplate clauses under various legal traditions, see Giuditta Corder-Moss (ed), Boilerplate Clauses, International Commercial Contracts and the Applicable Law (Cambridge University Press 2011). At the same time, doctrinal writings, uninformed by a functional method, demonstrate a tendency for more ready assertion that a distinction in interpretative approaches between various national laws may be exaggerated - see, for instance, Jonas Rosengren, 'Contract Interpretation in International Arbitration' (2013) 30 Journal of International Arbitration 1-16. Similarly, claims on convergence between the interpretative approaches of various laws are more easily inferred by those who are not using a functional method. For instance, while acknowledging the differences between 'interpretative cultures' in general terms, Alexander Komarov seems to affirm convergence between various approaches: '... at present, the development of law and practice in terms of the globalised world of international economic turnover indicates that the differences in principal approaches are now becoming less substantial than before' - see Alexander Komarov, 'Contract Interpretation and Gap Filling from the Prospect of the UNIDROIT Principles' (2017) 22(1) Uniform Law Review 29, 3 o. 
to a possible convergence or similarities in approaches between laws that are traditionally perceived as being distinct. ${ }^{11}$

If properly exercised, functional method is a demanding endeavour, as it anticipates the knowledgeable application of legal rules as practised in a particular country. Because of the difficulties, many scholars are satisfied with the dogmatic analysis that often focuses on various dichotomies that describe approaches to contract interpretation, such as the objective-subjective, textual-contextual, literal-broad approaches, etc. ${ }^{12}$ Not many studies apply it, but those that do so reveal a lot. ${ }^{13}$

11 See, for instance, Edward T Canuel, 'Comparing Exculpatory Clauses Under AngloAmerican Law: Testing Total Legal Convergence' in Giuditta Cordero-Moss (ed), Boilerplate Clauses, International Commercial Contracts and the Applicable Law (Cambridge University Press 2011) 80-103.

12 For instance, Gerard McMeel and Hans Christoph Grigoleit, 'Interpretation of Contracts' in Gerhard Dannemann and Stefan Vogenauer (eds), The Common European Sales Law in Context: Interactions with English and German Law (Oxford University Press 2013) 341372; Claus-Wilhelm Canaris and Hans Christoph Grigoleit, 'Interpretation of Contracts' in Arthur S Hartkamp and others (eds), Towards a European Civil Code (3rd edn, Kluwer Law International 2004) 445-469; Jacques H Herbots, 'Interpretation of Contracts', Elgar Encyclopedia of Comparative Law (Edward Elgar Publishing 2006) 325-347; James Spigelman, 'The Centrality of Contractual Interpretation: A Comparative Perspective' (2015) 81 Arbitration 234, 234-253; Stefan Vogenauer, 'Interpretation of Contracts: Concluding Comparative Observations' in Andrew Burrow and Edwin Peel (eds), Contract Terms (Oxford University Press 2008) 128-152; Catherine Valcke, 'Contractual Interpretation at Common Law and Civil Law: an Exercise in Comparative Legal Rhetoric' in Jason W Neyers, Richard Bronaugh and Stephen G A Pitel (eds), Exploring Contract Law (Hart Publishing 2009) 77-114; Alberto Luis Zuppi, 'The Parol Evidence Rule: a Comparative Study of the Common Law, the Civil Law Tradition, and Lex Mercatoria' (2007) 35 Georgia Journal of International and Comparative Law 233, 233-276; Blake D Morant, 'Contractual Interpretation in the Commercial Context' in Larry A DiMatteo and Martin Hogg (eds), Comparative Contract Law: British and American Perspective (Oxford University Press 2016) 248-271; Mark Van Hoecke, 'Deep Level Comparative Law' in Mark Van Hoecke (ed), Epistemology and Methodology of Comparative Law (Hart Publishing 2004) 172-174 (the work of Mark Van Hoecke is somewhat specific, as the author does not aim to compare contract interpretation under various laws; Van Hoecke rather discusses the methodological and epistemological difficulties of comparative law, using the example of contract interpretation. Nevertheless, similarities and distinctions are spotted on a dogmatic level without the application of a functional method); Filippo Viglione, 'Good Faith and Reasonableness in Contract Interpretation: A Comparative Perspective' (2009) 2o European Business Law Review 835, 835-850; Laurent Lévy and Fabrice Robert-Tissot, 'L'interprétation arbitrale' (2013) 4 Revue de l'Arbitrage 861, 861-952.

13 The works that apply a functional method and cover a broad range of jurisdictions are mostly the results of large projects. For example, the book on good faith, edited by Reinhard Zimmermann and Simon Whittaker, appeared as a result of the project on the Common Core of European Private Law - see Reinhard Zimmermann and Simon 
Having a primary objective to provide an analytical summary of the similarities and differences in contract interpretation across national laws, the chapter does not delve into the independent application of a functional method. Instead, it relies both on studies that were able, by applying a functional method, to animate and accentuate various similarities and distinctions in contract interpretation and those works that use other methods to investigate contract interpretation. ${ }^{14}$

The knowledge we possess now is primarily the result of two kinds of aspirations for comparative exercises: comparison for comparison and comparison for harmonisation. Comparison for comparison results in various publications on contract interpretation under national laws, some of which have already been mentioned above. Comparison for harmonisation ends up either with interstate or non-state unified instruments in the field of contract law, which boost comparative research in the course of the preparation of these instruments, and thereafter, following their appearance and, where relevant, application. Among the most influential interstate sources containing the uniform rules of contract interpretation, one can name the United Nations Convention on the Contracts on International Sales of Goods (CISG) and the EU regulation on unfair contract terms. While acknowledging the role of the parties' intent

Whittaker (eds), Good Faith in European Contract Law (Cambridge University Press 200o); the book, referenced earlier, on boilerplate clauses under various laws, appeared as a result of the 'Anglo-American Contract Models and Norwegian and Other Civil Law Governing Laws' project, run by Giuditta Cordero-Moss at the University of Oslo from 2004 to 2010 see Giuditta Cordero-Moss (ed), Boilerplate Clauses, International Commercial Contracts and the Applicable Law (Cambridge University Press 2011). Monographic works applying a functional method usually cover a limited number of jurisdictions. For instance, when investigating contract interpretation and gap filling, Nikole Kornet chose German, Dutch and English law - see Nikole Kornet, Contract Interpretation and Gap Filling: Comparative and Theoretical Perspectives (Intersentia 2006); Giuditta Cordero-Moss rather exceptionally covers Norwegian, German, Italian, and English law, and various transnational and international instruments - see Giuditta Cordero-Moss, 'Lectures on Comparative Law of Contracts' (2004) 166 Publications Series of the Institute of Private Law, University of Oslo 88-104. It is also important to note that functional method does not exclude other methods and approaches, for instance, law \& economics (see Nikole Kornet), or dogmatic analysis (book projects of Reinhard Zimmermann and Simon Whittaker on good faith, and of Giuditta Cordero-Moss on boilerplate clauses).

14 Scholarship relying on the dogmatic method has already been identified. The historical method may be evidenced by the work of Reinhard Zimmermann, The Law of Obligations: Roman Foundations of the Civilian Tradition (reprint edn, Oxford University Press 1996). The empirical method is well-represented, for instance, in Uri Benoliel, 'The Interpretation of Commercial Contracts: An Empirical Study' (2017) 69 Alabama Law Review 469 . 
for contract interpretation in Article 8, the CISG emphasises the necessity for objective analysis. ${ }^{15}$ The success of the CISG largely inspired subsequent initiatives on the harmonisation of contract rules and further work on contract interpretation in the UNIDRoIT Principles of International Commercial Contracts (UPICC), ${ }^{16}$ the Principle of European Contract Law (PECL), ${ }^{17}$ the Draft Common Frame of Reference (DCFR), ${ }^{18}$ and the draft Common European Sale Law (CESL). ${ }^{19}$ The Directive on Unfair Terms in Consumer Contracts, in turn introduced an interpretative presumption in favour of consumers. ${ }^{20}$ The presumption not only reflects the point of agreement for EU members but also for a growing number of other states. ${ }^{21}$

If comparative studies have informed and facilitated harmonising efforts, the harmonising efforts, in turn, have substantially enhanced the rise and quality of further comparative research for contract interpretation. The legal

15 Article 8 of the CISG is discussed in more detail, from the perspective of the uniform private law convention, in the next chapter. See also, Alberto Zuppi 'Article 8' in Stefan Kröll, Loukas A Mistelis and Pilar Rerales Viscasillas, UN Convention on Contracts for the International Sale of Goods (CISG): Commentary (C.H. Beck/Hart/Nomos 2011) 142-153.

16 Chapter 4 of the PIICL on contract interpretation has not sustained changes in all editions in 1994, 2004, 2010 and 2016 - see UNIDROIT, 'UNIDROIT Principles of International Commercial Contracts 2016' (2016) <https://www.unidroit.org/instruments/commerc ial-contracts/unidroit-principles-2016/> accessed 26 September 2021; UNIDroit, 'UNIDROIT Principles of International Commercial Contracts 2010' (2010) <https://www. unidroit.org/instruments/commercial-contracts/unidroit-principles-2010/> accessed 26 September 2021; UNIDROIT, 'UNIDROIT Principles of International Commercial Contracts 2004' (2004) <https://www.unidroit.org/wp-content/uploads/2021/06/Unidr oit-Principles-2004-English-i.pdf> accessed 26 September 2021; UNIDROIT, 'UNIDROIT Principles of International Commercial Contracts 1994' (1994) < www.unidroit.org/instruments/commercial-contracts/unidroit-principles-1994> accessed 25 June 2021.

17 Article 5:101-5:107 of the PECL - see Commission on European Contract Law, Principles of European Contract Law: Parts I and II (Kluwer Law International 200o).

18 Chapter 8 of the DCFR - see Study Group on a European Civil Code and Research Group on Ec Private Law, Principles, Definitions and Model Rules of European Private Law: Draft Common Frame of Reference (DCFR) (Sellier European Law Publishers 2009) 216-218.

19 Chapter 6 of the CESL - see European Commission, 'Proposal for a Regulation of the European Parliament and of the Council on a Common European Sales Law' ( Сом(2001) 635 final, 2011/o284 (COD), 11 October 2011) <https://eur-lex.europa.eu/legal-content/EN/ TXT/PDF/?uri=CELEX:52011PCo635\& from=EN $>$ accessed 25 June 2021.

20 Council Directive 93/13/EEC of 5 April 1993 on Unfair Terms in Consumer Contracts [1993] OJ L95/29 provides in recitals that: 'the consumer should actually be given an opportunity to examine all the terms and, if in doubt, the interpretation most favourable to the consumer should prevail'. See also Christian Twigg-Flesner, The Europeanisation of Contract Law: Current Controversies in Law (2nd edn, Routledge 2013) 52-116.

21 For instance, Article 18 of the Law of Ukraine 'On Protection of Consumers Rights' of 1991 with amendments. 
science has benefited enormously from the self-refection of this comparative twist. The harmonised instruments' practical success has not played a decisive role in the growth of this scholarly interest: their mere existence has triggered attention. ${ }^{22}$ Scholars have started to compare the harmonised international and transnational sources with national laws and investigate their relationship. While demonstrating an aspiration for uniformity and neutrality, ${ }^{23}$ the harmonised sources showed how much they were affected by a particular national legal tradition. ${ }^{24}$ The resulting studies have affirmed a predominant approach to contract interpretation as a legal question and not merely as a question of facts. ${ }^{25}$ They have revealed a great deal about the diversity of the doctrines relevant to contract interpretation across various legal traditions

22 For instance, the CISG currently has 94 contracting parties (UNCITRAL, 'Status: United Nations Convention on Contracts for the International Sale of Goods (Vienna, 1980)' $<$ https://uncitral.un.org/en/texts/salegoods/conventions/sale_of_goods/cisg/> accessed 26 September 2021, whereas the PECL and the DCFR remained academic initiatives.

23 Stefan Vogenauer, 'General Principles' of Contract Law in Transnational Instruments' in Louise Gullifer and Stefan Vogenauer (eds), English and European Perspectives on Contract and Commercial Law: Essays in Honour of Hugh Beale (Hart Publishing 2014) 291-318.

24 Giuditta Cordero-Moss, for instance, makes a (delicate) observation on the influence of Romanistic legal tradition in the UPICC and Nordic tradition in the PECL: 'The transnational restatements follow the Civil Law tradition in this context (and so does the CISG, but only to a limited extent). It might be tempting to notice an interesting symmetry: While the PECL, where the works have been led by a Nordic professor, have an approach that is close to the Germanic-Nordic tradition, the UNIDROIT Principles, where the works were led by an Italian professor, have an approach that is close to the Romanistic tradition. However, in view of the truly international composition, attitude and research that characterised both restatements, it seems unlikely that the legal background of the respective chairmen might have played such an important role' - see Giuditta Cordero-Moss, 'Lectures on Comparative Law of Contracts' (2004) 166 Publications Series of the Institute of Private Law, University of Oslo 100-101.

25 For the UPICC, see, for instance, clarification of Stefan Vogenauer who explains: 'Questions on contractual interpretation are therefore questions of law and not questions of fact. In this respect, the PICC [the UPICC] differ from some domestic contract laws, such as French law, or as far as oral contracts are concerned, English law. The effects of this classification depend on the procedural rules of the forum. For example, questions of law are typically open to review at the appellate level whilst questions of fact are not, questions of law may be for the judge rather than for the jury, etc.' - Stefan Vogenauer, '4: Interpretation' in Stefan Vogenauer (ed), Commentary on the UNIDROIT Principles of International Commercial Contracts (PICC) (2nd edn, Oxford University Press 2015) 497. On the factual approach to contract interpretation primarily because of the peculiarities of the organisation of justice in France and the USA, see further in the texts of this chapter; see also Ahmet Cemil Yildirim, Interpretation of Contracts in Comparative and Uniform Law (Kluwer Law International 2019) 37-39, 108-124. 
and the overall sensitivity of contract interpretation for a national legal tradition. ${ }^{26}$

Interestingly enough, the comparison of contract interpretation in national and transnational instruments spans not only academia, but also politics. A discussion of the DCFR in the House of Lords, in the UK, is illustrative in this regard. In 2008, Stefan Vogenauer, who was Professor of Comparative Law at the University of Oxford at that time, was asked to prepare a memorandum on a number of issues relating to the DCFR and to appear as a witness for testimony before the House of Lords. In the memorandum, he stressed various areas of distinctions between the DCFR and English contract law, particularly emphasising the broad scope of the principle of good faith and fair dealing contained in the DCFR. Over the course of questioning, when asked to give examples of the practical nature of the differences between the DCF R and English law, Vogenauer chose to comment on contract interpretation:

If we look at more practical issues, and I would like to come to deeper issues later because they may be more significant in the long run, a very practical issue that arises quite often in the interpretation of contracts is that English law does not allow recourse to the preliminary negotiations, they are not to be used as an aid to the interpretation of contracts. Although much has changed in the law of contractual interpretation over the last ten or 15 years, as Lord Steyn once said that is a sacred cow of English contract law. The Draft Common Frame of Reference would admit those statements as aids to interpretation, which might lead to a very different outcome in a particular case. ${ }^{27}$

The final report of the House of Lords referred to differences mentioned by Stefan Vogenauer as a demonstration of the civilian approach that may undermine certainty, and result in what was referred to as 'often inconclusive

26 For contemporaneous comparison of the DCFR with EC contract law see Reiner Schulze (ed), Common Frame of Reference and Existing EC Contract Law (2nd edn, Sellier European Law Publishers 2009). For comparison of the CESL with German and English contract law see Gerard McMeel and Hans Christoph Grigoleit, 'Interpretation of Contracts' in Gerhard Dannemann and Stefan Vogenauer (eds), The Common European Sales Law in Context: Interactions with English and German Law (Oxford University Press 2013) 341-372.

27 'European Contract Law: the Draft Common Frame of Reference - European Union Committee Contents, Examination of Witness Professor Stefan Vogenauer' (26 November 2008) <https:/publications.parliament.uk/pa/ld20o8og/ldselect/ldeucom/95/81126o3.htm> accessed 25 June 2021. 
investigation of pre-contractual discussions and subjective intentions' ${ }^{28}$ Similar debates at various venues can be found in relation to other suggested instruments, including the latest CESL initiative. ${ }^{29}$

A further awareness of the differences in the regulation of contract interpretation under various national laws emerges from scholarship focused on the noticeable practice in international commercial arbitration where arbitral tribunals interpret contracts simply from the perspectives of reasonableness and business sense and with entire disengagement from applicable national law. This interpretative approach has been increasingly criticised by various scholars, including Joshua Karton, Giuditta Cordero-Moss and Gary Born, to name a few. Karton illustrated the widespread misconception about the capacity of international arbitration to disengage contract interpretation from applicable national law by providing a thorough overview of various publications supporting, negating or diminishing the role of national law in contract interpretation..$^{30}$ Cordero-Moss developed an argument in support of national law

28 'European Contract Law: the Draft Common Frame of Reference - European Union Committee Contents, Chapter 3: The Draft CFR' (2009) <https://publications.parliament. $\mathrm{uk} / \mathrm{pa} / \mathrm{ld} 2008 \mathrm{og} / \mathrm{ldselect} / \mathrm{ldeucom} / 95 / 9506 . \mathrm{htm} \# \mathrm{a} 7>$ accessed 25 June 2021.

29 In 2012, the Bar Council of England \& Wales issued its response to the UK government's call for evidence on the Common European Sales Law in which it criticised the Commission's October 2011 proposal calling additional principles of contract interpretation 'broad and vague.' The Bar Council also warned of the possible educational burden and costs as such principles are unfamiliar to lawyers and judges in some Member States. See Bar Council of England and Wales, 'Bar Council of England \& Wales response to UK Government call for evidence on the Common European Sales Law' (May 2012) <www. barcouncil.org.uk/media/159762/barcouncilof_england___wales__response_to_moj__ bis_call_on_cesl_may2012final.pdf> accessed 3 May 2018. See also a discussion of the CESL in the parliaments of Germany and the UK - European Parliament Committee on Legal Affairs, 'Notice to Members: Reasoned Opinion by the Bundestag of the Federal Republic of Germany on the Proposal for a Regulation of the European Parliament and of the Council on a Common European Sales Law' (Сом(2011)o635, 2011/o284(COD), 16 December 2011) <www.europarl.europa.eu/RegData/commissions/juri/communication/ 2011/478528/JURI_CM $(2011) 478528$ EN.pdf $>$ accessed 25June 2021.

30 Karton's overview includes the astonishingly straightforward assertion of the ICC in 2014, which suggested that: 'Arbitrators are not beholden to national legal systems. They enjoy greater freedom than state courts when engaging in contractual interpretation.' Karton also refers to publications of well-known scholars and arbitrators (including Julian Lew, Karl-Heinz Böckstiegel, Derains and others), in addition to the result of interviews conducted with 20 active arbitrators and an overview of 73 arbitral awards - see Joshua Karton, 'The Arbitral Role in Contractual Interpretation' (2015) 6 Journal of International Dispute Settlement 4, 4-41. The sources cited by Karton may be viewed as variations of a large theme that evolves in parallel to scholarly writings and emphasises the transformation of international arbitration from occasional private justice in individual cases to legitimised private justice exercised by the arbitration community - see, for instance, 
for contract interpretation from various angles, including the limits of party autonomy in international commercial arbitration, ${ }^{31}$ the impossibility to fully disengage international contracts from applicable governing law, ${ }^{32}$ the continuous importance of conflict of laws rules for international commercial arbitration, ${ }^{33}$ substantial distinctions in approaches towards contract interpretation under various national laws, ${ }^{34}$ the limitations of the transnational sources

Dolores Bentolia, Arbitrators as Lawmakers (International Arbitration Law Library Series Volume 43, Kluwer Law International 2017) 145-194, including fn 8o8-814 in the book. While the idea of the transformed character of international commercial arbitration, resulting in the emerged community of international arbitrators, may be persuasive in general terms, it is still vulnerable in the face of the normative criticism that emphasises a positivist account of national law as an unavoidable legal source. Precisely for this failure of not developing a normative claim on the autonomy of international arbitration, Stavros Brekoulakis criticises the scholarship on international arbitration - see Stavros L Brekoulakis, 'International Arbitration Scholarship and the Concept of Arbitration Law' (2013) 36 (4) Fordham International Law Journal 745, 745-787.

31 Giuditta Cordero-Moss, 'Limitations on Party Autonomy in International Commercial Arbitration' (2014) 372 Recueil des Cours de l'Académie de Droit International 133-326. While the title of the monograph emphasises the limits of party autonomy, the underlined idea revolves around the deep and more subtle question of contract interpretation in international commercial arbitration. The monograph may be also viewed as a summary of the arguments on the significance of the role of national law for contract interpretation.

32 Giuditta Cordero-Moss, 'Does the Use of Common Law Contract Models Give Rise to Tacit Choice of Law or to a Harmonised, Transnational Interpretation?' in Giuditta Cordero-Moss (ed), Boilerplate Clauses, International Commercial Contracts and the Applicable Law (Cambridge University Press 2011) 37 - 61; Giuditta Cordero-Moss, 'Conclusion: the Self-sufficient Contract, Uniformly Interpreted on the Basis of Its Own Terms: an Illusion, but not Fully Useless' in Giuditta Cordero-Moss (ed), Boilerplate Clauses, International Commercial Contracts and the Applicable Law (Cambridge University Press 2011) 344-373; Giuditta Cordero-Moss, 'International Arbitration Is not Only International' in Giuditta Cordero-Moss (ed), International Commercial Arbitration (Cambridge University Press 2013) 7 - 39; Giuditta Cordero-Moss, 'International Arbitration and Commercial Contract Interpretation: Contract Wording, Common Law, Civil Law and Transnational Law' in Göran Millqvist and others (eds), Essays in Honour of Michael Bogdan (Juristförlaget 2013) 33 - 57; Giuditta Cordero-Moss, 'Interpretation of Contracts in International Commercial Arbitration: Diversity on More than One Level' (2014) 22 European Review of Private Law art. 3, 13-36.

33 Giuditta Cordero-Moss, 'International Arbitration and the Quest for the Applicable Law' (2008) 8 Global Jurist 1, 1-42.

34 Giuditta Cordero-Moss, 'The Importance of Legal Culture for Contract Construction: Norwegian Law, English Law and International Arbitration' (2017) 10(1) New York Dispute Resolution Lawyer 39, 39-41; Giuditta Cordero-Moss, 'Some Observations on the Significance of Local Law for Energy Contracts - the Example of Norwegian Law' (2017) 2(1) European Investment Law and Arbitration Review 258, 258-276; Giuditta 
as applicable rules ${ }^{35}$ and the hidden influences of national law traditions on contract interpretation. ${ }^{36}$ Gary Born methodologically elucidates the various areas in which substantive applicable law matters, including contract interpretation. ${ }^{37}$ Scholarship focused on investment treaty arbitration stands apart from this discourse and this work aims to fill the gap.

Another increasingly noticeable development in international arbitration (which is still in its infancy) can enhance our awareness of the role of the proper law for contract interpretation. Studies of unconscious or implied biases in international commercial arbitration may reveal how national legal traditions can form certain unexpressed expectations among arbitrators in respect to contract interpretation. ${ }^{38}$ This is another extreme, which, instead of disengaging the contract from any applicable national law, subjects it to the hidden application of another law. Biases informed by national law traditions may lead arbitrators, for instance, to expect the submission of contextual evidence relating to pre-contractual negotiations or post-contractual conduct, in which the contract is governed by English law, under which such evidence is forbidden. Conversely, an arbitrator from a common law tradition may be more prepared/inclined to disregard contextual evidence as irrelevant, when the contract is in fact governed by Ukrainian law, which enables contextual evidence to be considered. To date, no thorough investigation has been conducted in this field. The literature available consists either of anecdotal descriptions ${ }^{39}$ or

Cordero-Moss, 'Lectures on Comparative Law of Contracts' (2004) 166 Publications Series of the Institute of Private Law, University of Oslo 1-194.

35 Giuditta Cordero-Moss, International Commercial Contracts: Applicable Sources and Enforceability (Cambridge University Press 2014).

36 Giuditta Cordero-Moss, 'Non-national Sources in International Commercial Arbitration and the Hidden Influence by National Traditions' in (2017) 63 Scandinavian Studies in Law 23, 23-43.

37 Gary Born, International Commercial Arbitration (2nd edn, Kluwer Law International 2014) 1317-1403, 2614-2778.

38 Stavros L Brekoulakis conceptualises implicit biases, as opposed to apparent biases, relating to the personal or financial interests of an arbitrator. According to Brekoulakis, implicit biases originate from the 'values and cognition of arbitrators, as well as the culture embedded in international arbitration' - see Stavros L Brekoulakis, 'Systemic Bias and the Institution of International Arbitration: A New Approach to Arbitral Decision-Making' in Tony Cole (ed), The Roles of Psychology in International Arbitration (International Arbitration Law Library Series Volume 40, Kluwer Law International 2017) 346-349.

39 William W. Park, for instance, describes the biases of the counsel who failed to address post-contractual conduct in aid of contract interpretation that was subjected to New York law primarily because of their background in English law. The tribunal directed the parties to the possibility of presenting evidence on post-contractual conduct - see William W Park, 'Rules and Reliability: How Arbitrators Decide' in Tony Cole (ed), The Roles of 
of calls for greater multidisciplinary research. ${ }^{40}$ It is, however, clear that with both examples being either about the non-application of any national law to contract interpretation or a hidden reliance on a law which has been erroneously subconsciously applied, the result may deviate from what the proper law of the contract ensures. In both situations, the results would also differ from what the parties legitimately expect when they choose the law applicable to the contract or what can be reasonably expected because of the applicable conflict of laws provisions, if the parties fail to agree on the applicable law.

Even though as a result of comparison for comparison, comparison for harmonisation and research on international arbitration, we know substantially more about contract interpretation from a comparative perspective, the proposition as to the lack of comprehensive comparative coverage of all laws still remains valid. Not having an ambition to fill the existent gap in the knowledge on the precise distinctions among various national laws on contract interpretation in this work, it would suffice at this stage to refer to some fundamental findings spotting important differences by way of illustration. We currently understand that not only interpretative approaches as such may differ, but it may well be that various jurisdictions have somewhat different perspectives on other relevant aspects, including, for instance, sources by which contract interpretation is regulated, the role of an interpreter impacting what is ultimately perceived

Psychology in International Arbitration (International Arbitration Law Library Series Volume 40, Kluwer Law International 2017) 12-13.

40 Giuditta Cordero-Moss discusses the desirability of the multidisciplinary method in addressing unconscious psychological influences of the legal culture on contract interpretation, indicating the relevant disciplines that could contribute to this, and formulating a research question for such studies - 'to what extent the construction of a contract or application of the transnational law is influenced by the interpreter's legal culture' - see Giuditta Cordero-Moss, 'Non-national Sources in International Commercial Arbitration and the Hidden Influence by National Traditions' (2016) 63 Scandinavian Studies in Law 23, 41. Having overviewed the studies on arbitral decision-making, Stavros L Brekoulakis criticises the limits of the behavioural and attitudinal approaches and calls for a multi-methodological institutional study, with the following suggestion: 'whether, for example, certain values and ideology are embedded into international arbitration, which implicitly inform the judicial attitude of the individuals acting as arbitrators; whether international arbitration over time has developed informal processes that implicitly shape the legal concepts of those involved in the practice and teaching or arbitration; whether there are mechanisms in place that ensure that any individual who aspires to enter the world of international arbitration, espouses certain legal values and ideological assumptions that conserve the status quo of international arbitration' - see Stavros L Brekoulakis, 'Systemic Bias and the Institution of International Arbitration: A New Approach to Arbitral Decision-Making' in Tony Cole (ed), The Roles of Psychology in International Arbitration (International Arbitration Law Library Series Volume 40, Kluwer Law International 2017) 371. 
as contract interpretation, the grounds triggering/necessitating contract interpretation, the priority order of application of certain interpretative rules and canons of interpretation, or evidentiary matters pertaining to contract interpretation, etc. Below is an overview of the most significant and ascertainable similarities and distinctions.

\subsection{The Concept of Contract Interpretation}

One typically understands the concept of contract interpretation as a type of legal interpretation aiming at ascertaining the parties' joint intent. The focus on intent naturally follows from the object of interpretation - a contract. By entering into the contract, parties agree to assume mutual individualised undertakings. To give effect to these undertakings, an interpreter (a judge or an arbitrator) has to find out what the parties meant, i.e. their joint intent. Implicitly ${ }^{41}$ or explicitly, ${ }^{42}$ the focus on intent appears central to contract interpretation and distinguishes this type of legal interpretation from statutory interpretation. ${ }^{43}$

Further, following the mainstream of philosophical hermeneutics that argues that language is inherently ambiguous and that every text requires interpretation, it has become more readily acceptable nowadays that a conclusion that a contractual provision is clear also represents an act of interpretation. ${ }^{44}$ To understand the development, one may start with Roman law. In early Roman law, the maxima attributed to Paulus cum in verbis ambiguitas est, non debet admitti voluntatis quaestio suggested that only ambiguous words required investigation of the parties' will. With time, when Roman contract law moved to become less formalist, the maxima was reversed, whereas in medieval and Renaissance times, lawyers again accepted that clear words excluded

41 The fact that some laws, like the law of England and Wales, prioritise textual or literal interpretation does not mean that parties' joint intent is not considered. See, Catherine Mitchell, Interpretation of Contracts: Current Controversies in Law (Routledge 2007) 32-33. Article 431 of the Civil Code of the Russian Federation, Article 447 (1) of the Civil Code of Armenia, Article 401 of the Civil Code of Byelorussia and Article 392 (1) of the Civil Code of Kazakhstan stipulate that the joint intent of the parties has to be considered if the literal meaning does not enable the clarification of the content of the contractual provisions.

43 For a detailed discussion on the peculiarities of statutory interpretation, see Stefan Vogenauer, 'Statutory Interpretation' in Jan M Smits (ed), Elgar Encyclopedia of Comparative Law (Edward Elgar Publishing 2006) 677-687.

44 See, for instance, Aharon Barak, Purposive Interpretation in Law (Princeton University Press 2005) 11-14, 54-6o. 
the investigation of the parties' will. ${ }^{45}$ Nowadays a heritage of Roman law - the provision on les clauses claires et précises under French law and the principle of in claris non fit interpretatio under Italian law - instead of excluding contract interpretation of clear provisions as such, should rather be understood as reflecting an initial stage in contract interpretation. In France, regulation of clear contractual clauses plays a specific role that ensures control by higher courts over interpretation, which is otherwise excluded. ${ }^{46}$ In Italy, the principle has received a more distinct feature as a canon of interpretation, bringing Italian law closer to English law in the approach to contract interpretation. ${ }^{47}$

What really divides jurisdictions in their understanding of contract interpretation as a concept, is the role of an interpreter vis-à-vis contractual text. Some jurisdictions may accept, relatively readily, that an interpreter goes beyond the text of a contract, ${ }^{48}$ while others may not. ${ }^{49}$ The differences essentially reflect the acceptable frontiers for contract interpretation for each jurisdiction, or in other words distinguishes contract interpretation from other borderline analytical efforts in relation to contracts.

By way of example, the laws belonging to the civil law tradition indeed frequently differentiate between simple, or genuine, interpretation, on the one

45 Reinhard Zimmermann, The Law of Obligations: Roman Foundations of the Civilian Tradition (reprint edn, Oxford University Press 1996) 621-650 (Zimmermann draws connection between the Paulus maxima and objective preferences in German law and 'plain meaning' rule in English law); Ian Maclean, Interpretation and Meaning in the Renaissance: The Case of Law (Cambridge University Press 1992) 89-9o.

46 For contract interpretation under French law, see Jan M Smits, Contract Law: A Comparative Introduction (2nd edn, Edward Elgar Publishing 2017); Marcel Fontaine and Filip de Ly, Drafting International Contracts (Martinus Nijhoff Publishers 2009) 108, Ahmet Cemil Yildirim, Interpretation of Contracts in Comparative and Uniform Law (Kluwer Law International 2019) 37-39; see also the discussion on procedural peculiarities associated with treatment of contract interpretation as a question of fact in France in Chapter 4 of this work.

47 For contract interpretation under Italian law, see Giuditta Cordero Moss, 'International Contracts between Common Law and Civil Law: Is Non-state Law to Be Preferred? The Difficulty of Interpreting Legal Standards Such as Good Faith' (2007) 7(1) Global Jurist art. 3, 17; Ahmet Cemil Yildirim, Interpretation of Contracts in Comparative and Uniform Law (Kluwer Law International 2019) 41-43.

48 For example, in German, Portuguese, French, Austrian and Belgian laws - see Ole Lando and Hugh Beale (eds), Principles of European Contract Law (Kluwer Law International 2000) 305; Axel-Volkmar Jaeger and Götz-Sebastian Hök, FIDIC - A Guide for Practitioners (Springer 2010) 173; Danny Busch and others (eds), The Principles of European Contract Law and Dutch Law: A Commentary (Kluwer Law International 2002) 241.

49 For example, English and Irish law - see Ole Lando and Hugh Beale (eds), Principles of European Contract Law (Kluwer Law International 2000) 305. 
hand, and more qualified types of contract interpretation. Interpretative construction or supplementary interpretation in these jurisdictions may refer to a variety of distinct exercises, all of which are part of contract interpretation. An interpreter may be authorised to supplement those terms which parties fail to agree on and that can be implied from the relevant express statutory regulation. An interpreter may also be engaged in a more intense interpretative effort that is not exclusively based on supplementation on the basis of statutory regulation. Furthermore, though with more caution and rather exceptionally, certain civil laws may be more inclined to include the construction of omitted terms in an interpretative exercise and authorise corrective interpretation, which would downplay certain contractual terms.

Unlike civil law tradition, it is more difficult for the laws belonging to the common law tradition to accept that an interpreter can go beyond the text of a contract. ${ }^{50}$ On a conceptual level, common law tradition differentiates more firmly between genuine interpretation as hermeneutic understanding of the contractual terms and the construction and supplementation of terms as distinct (non-interpretative) analytical exercises. For instance, if the text of a contract does not suffice, a functional equivalent to the qualified interpretation - a doctrine of implied terms - may be relied upon to respond to unnecessary formalism. ${ }^{51}$ Leading to a similar result as a qualified contract interpretation, the doctrine nevertheless is conceptually distinct from contract interpretation.

50 For a comparison of a broad concept of contract interpretation under Norwegian law and a narrower concept of contract interpretation under English law, see Alf Petter Høgberg, 'Avtaletolkning - om forutberegnelighet og rimelighet i nordisk tradisjon' in Mads Bryde Andersen and others (eds), Aftaleloven 100 år. Baggrund, status, udfordinger, fremtid (DJøF Publishing Copenhagen 2015) 160-161; on the distinctions between interpretation and construction in the USA, see Gregory Klass, 'Interpretation and Construction in Contract Law' (2018) Georgetown Law Faculty Publications and Other Works 1, 1-48; Ahmet Cemil Yildirim, Interpretation of Contracts in Comparative and Uniform Law (Kluwer Law International 2019) 108-109.

$5^{1}$ Save for some exceptions, the common law tradition keeps the doctrine of implied terms conceptually distinct from contract interpretation. The doctrine of implied terms emerged from statutory supplementation in sales contracts and developed further to such sources of implication as trade usages, customs and factual circumstances surrounding a contract. By justifying implication or supplementation of the terms, common law courts may introduce considerations of intent into reasoning, but it does not necessarily reflect the activity as being contract interpretation. For scholarship addressing various aspects of the doctrine of implied terms under English law, see Richard Austen-Baker, Implied Terms in English Contract Law (2nd edn, Edward Elgar Publishing 2017) 3-4, 76-95, 136-170; Gerard McMeel, Construction of Contracts: Interpretation, Implication, and Rectification (3rd edn, Oxford University Press 2017); Nicole Kornet, Contract Interpretation and Gap Filling: Comparative and Theoretical Perspectives (Intersentia Publishers 2006) 247-255; T T Arvind, Contract Law (Oxford University Press 2017) 223-225; Richard Stone and 
Overall, one has to conclude by saying that conceptually viewed contract interpretation is not identical across jurisdictions. The mere focus on the parties' intent does not render the concept aligned across jurisdictions. While the distinctions between interpretative and non-interpretative analytical exercises are not always clear-cut, even for those jurisdictions that tend to maintain the distinction, ${ }^{52}$ they suffice to warn against bare assumptions on the similarities in the role of an interpreter across jurisdictions.

\section{$2.3 \quad$ Regulation}

Jurisdictions differ as to the availability of the statutory precepts of interpretative rules ${ }^{53}$ relevant to contract interpretation. Civil law countries traditionally carry out statutory regulation of contract interpretation. ${ }^{54}$ Common

James Devenney, The Modern Law of Contract (12 edn, Routledge 2017) 214; Catherine Mitchell, Interpretation of Contracts (1st edn, Routledge 2007) 23-26; Lord Hoffmann 'The Intolerable Wrestle with Words and Meanings' (1997) 114 South African Law Journal 656; Lord Justice Lewison, The Interpretation of Contracts (6th edn, Sweet \& Maxwell 2017) 282-285; John Cartwright, Contract Law: An Introduction to the English Law of Contract for the Civil Lawyer (3rd edn, Hart Publishing 2016) 210-217.

52 Supplying an omitted term under Section 204 of the American Restatement (Second) may not always be easy to distinguish from contract interpretation - Robert Braucher, 'Interpretation and Legal Effect in the Second Restatement of Contracts' (Symposium on the Restatement (2d) of Contracts) (1981) 81 (1) Columbia Law Review 13, 15. Commenting on Article 4.8 of the UPICC, Stefan Vogenauer, for instance, observes distinctions under national law and concludes on the impossibility to draw a 'bright line' between interpretation, supplementation and implication of contractual terms - Stefan Vogenauer (ed), Commentary on the UNIDROIT Principles of International Commercial Contracts (2nd edn, Oxford University Press 2015) 534.

53 For the specific nature and importance of interpretative rules, see Aharon Barak, Purposive Interpretation in Law (Princeton University Press 2005) 47-49.

54 For instance, Article 1198 of the Civil Code of Argentina and Article 218 of the Commercial Code of Argentina, Section 914-915 of the General Civil Code of Austria, Article 11561164 of the Civil Code of Belgium, Article 20 of the Law of Obligations and Contracts of Bulgaria, Article 125 of the Chinese Law on Contracts, Articles 1188-1192 of the Civil Code of France, Sections 133 and 157 of the German вGB, Articles 173 and 200 of the Greek Civil Code, Articles $1362-1371$ of the Italian Civil Code, Articles 6.193-6.195 of the Civil Code of Lithuania, Articles 1266-1269 of the Civil Code of Romania, Article 1281-89 of the Civil Code of Spain, Article of 637 of the Civil Code of Ukraine, etc. It may be interesting to learn that during Soviet times, the civil codes of the Soviet republics did not contain express regulation of contract interpretation. With the commercialised relationships, it was felt necessary for the new civil codes of the post-Soviet republics to expressly address contract interpretation in order to guide judges over contract interpretation - see 
law countries traditionally develop contract interpretation via judicial precedents. ${ }^{55}$ The divide between statutory regulation and judicial guidance for contract interpretation does not necessarily follow a classical divide between sources of legal rules in common and civil law traditions. Due to its nature pertaining to legal reasoning, contract interpretation turns to a fruitful and quite natural field for judicial clarifications, even for civil law tradition. Some civil law countries even demonstrate what can be externally perceived as a radical decision, completely reversing them from the statutory regulation of contract interpretation to judicial guidance. ${ }^{56}$ Others, while retaining statutory regulation of contract interpretation, experience an increase in the role of judicial clarifications in the field of contract interpretation. ${ }^{57}$

Article 401 of the Civil Code of the Byelorussia, Article 431 of the Civil Code of the Russian Federation and Articles 213 and 613 of the Civil Code of Ukraine.

55 For English law on contract interpretation, for instance, the following precedents are of note: Investors Compensation Scheme v. West Bromwich Building Society [1998] 1 WLR 896 (HL); Rainy Sky SA and others v. Kookim Bank [2011] UKSC 5O, [2011] 1 WLR 29oo, [2010] EWCA Civ 582, [2011] 1 Lloyd's Rep 233; BMA Special Opportunity Hub Fund Ltd and others $v$. African Minerals Finance Ltd [2013] EWSA Civ 416. For a discussion of these and other precedents in the field of contract interpretation, see also Catherine Mitchell, Interpretation of Contracts (2nd edn, Routledge 2019).

56 The Netherlands, for instance, while adopting the new Civil Code in 1992 chose not to include what were earlier express statutory provisions on contract interpretation of the old Civil Code. The rationale behind the decision underlined the necessity to retain flexibility in interpretative approaches through judicial guidance that was significant already prior to the adoption of the new Civil Code. The Haviltex case from the pre-reform period is still considered influential. In this case, the Dutch Supreme Court emphasised the necessity to establish the parties' intent and decided to go beyond the visibility of clear contract language - see Ermes v. Haviltex, HR 13 March 1981, NJ 1981, 635; Sanne Taekema, Anni de Roo and Carinne Elion-Valter (eds), Understanding Dutch Law (Eleven International Publishing 2011) 265-267; Jacques H Herbots, 'Interpretation of Contracts' Jan M Smits (ed), Elgar Encyclopedia of Comparative Law (Edward Elgar Publishing 2006) 332; Mark Wissink, 'Legal Certainty and the Construction of Contracts in Dutch Law' in Alex Geert Castermans and others (eds), Foreseen and Unforeseen Circumstances (Kluwer Law International 2012) 41-55.

57 For instance, in Ukraine, Articles 213 and 637 of Civil Code of Ukraine establish the basic statutory requirements for the interpretation of contracts and the procedures which should be followed. At the same time, much of the clarification comes from judicial practice. On 6 November 2009, the Plenum of the Supreme Court of Ukraine adopted Regulation No 9 specifying that courts may interpret contracts only in adversary proceedings, at the request of a party or parties or their successors. The High Commercial Court of Ukraine also clarified in their decisions the grounds and purposes for interpreting contracts by the court, the prohibition of creating new contractual clauses as a result of interpretation, etc. - see Decision of the High Commercial Court of Ukraine, Case 920/696/ 16, 29 March 2017; Decision of the High Commercial Court of Ukraine, Case 910/4938/ 16, 12 December 2016; Decision of High Commercial Court of Ukraine, Case 15/o70-12, 
As contracts come into existence as a matter of national law and cannot operate in entire isolation from it, a broader set of substantive regulations, or background laws, ${ }^{58}$ also influence contract interpretation, in addition to the interpretative rules evidenced by statutory precepts and judicial clarification. The law applicable to a contract does not merely define the limits of party autonomy; it represents a normative universe to which an interpreter commits (see Figure 3 on the next page). National law, thus relevant for contract interpretation, serves as a basis for the implication of contractual terms on the basis of specific statutory regulation, known to various extents both for civil and common law traditions. National law, thus relevant for contract interpretation, also sets deeper ties penetrating and growing through the entire contract, either because of the core of a contract and civil law regulation or because of specialised regulation relevant for a specific contract. As part of general contract law, the rules relate to fundamental principles of contract law, which, along with contract interpretation, inform various other borderline concepts of contract law, such as contract validity, termination, mistake, etc. As will be demonstrated by the example of good faith, even when these rules or principles are not framed as interpretative rules, they may nevertheless guide an interpreter in contract interpretation. As part of general specialised regulation, the relevant rules of national law may pertain to non-contractual fields of laws, such as competition law or to various specific fields of contracting, including public-private partnership, oil and gas, media, etc.

Either in statutory precepts or judicial clarifications, national law regulations affecting contract interpretation are not set in stone. The rules may evolve. Throughout the larger historical period, one may observe some of the most dramatic changes to contract interpretation. Giving rise to the European

16 July 2013. On18 April 2018, the Supreme Court, in its mandatory clarification for the lower courts, introduced the contra proferentem principle, which has to be applied as a last resort, both for those terms that were not individually negotiated and those that were included because of the dominant influence of one of the parties - see Decision of the Supreme Court, Case No 753/1100o/14-ц, 18 April 2018.

$5^{8}$ One may observe an increasing attention to the relevance of background law for contract interpretation in the scholarship. To what extent a background law may matter for contract interpretation also varies across jurisdictions. For a discussion of the relevance of background law in the Norwegian context, see Amund Bjøranger Tørum, Interpretation of Commercial Contracts (Universitetsforlaget 2019) 144-180; Ivar Alvik, 'Alminnelige kontraktsrettslige prinsipper og kontraktstyper i norsk rett' (2017) $5^{2}$ (6) Jussens venner, 378-405; Inger Berg Ørstavik, 'Konkurranserettens betydning ved tolkning og utfylling av avtaler' (2016), Tidsskrift for rettsvitenskap, 372- 418; Alf Petter Høgberg, Kontraktstolkning: særlig om tolkningsstiler ved fortolkning av skriftlige kontrakter (Universitetsforslaget 2006) 164-167. 


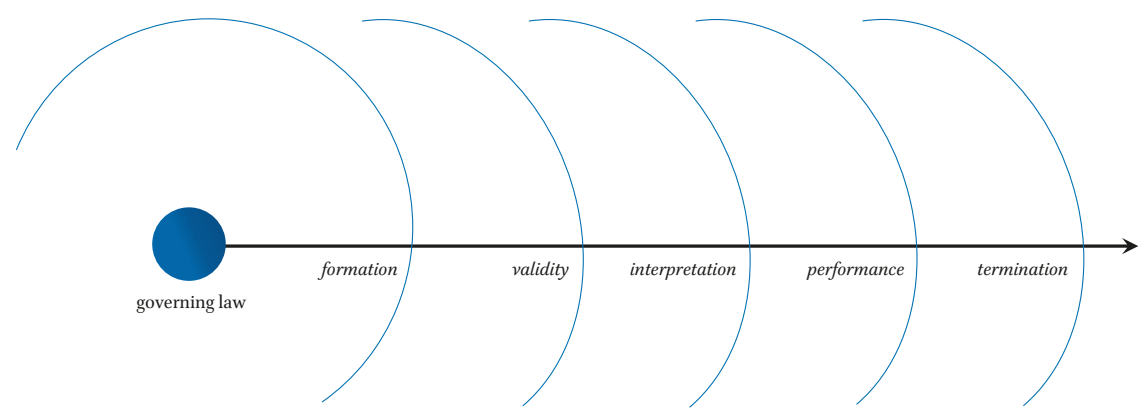

FIGURE 3 Effect of the governing national law upon a contract

contract law tradition over the centuries, contract interpretation in Roman law steadily moved from verba to voluntatis, i.e. from strict adherence to the words of a contract in the pre-classical period to obsession with subjective intent in post-classical jurisprudence. The maturity of contract interpretation reflected the changes in values and policies within society. When verba was in focus in contract interpretation, the underlined period demonstrated an adherence to strict and very formal rituals for any legal act. In Zimmermann's words, [ $[t] h e$ smallest mistake, a cough or stutter, the use of a wrong term invalidated the whole act..$^{59}$ Being surrounded by a formal set of protocols, the status of contracts were raised beyond ordinary life to legally significant acts. Voluntatis, for an interpreter, corresponded to an increased role of moral and Christian values in society that became the standard of assessment of human behaviour, including in contracting. ${ }^{60}$ Investigating verba did not necessitate a sophisticated set of canons for interpretation or evidence. The task of an interpreter was quite straightforward in meticulously assessing compliance with all necessary rituals. The investigation of voluntatis, in turn, required the development of various canons of interpretation, which later, according to certain sources, amounted to no less than one hundred different interpretative rules. ${ }^{61}$ Some of these canons of interpretation found their way into modern law and continue to be relied upon in modern jurisprudence. The role of evidence has also

59 Reinhard Zimmermann, The Law of Obligations: Roman Foundations of the Civilian Tradition (reprint edn, Oxford University Press 1996) 622.

6 Ibid. 624 .

61 In referring to more than one hundred interpretive rules, Zimmermann cites Hans Erich Troje, 'Ambiguitas Contra Stipulorem' (1961) 27 Studia et documenta historiae et juris 96, 105 - see fn 106 in Reinhard Zimmermann, The Law of Obligations: Roman Foundations of the Civilian Tradition (reprint edn, Oxford University Press 1996) 634. 
significantly increased because interpreters attempted to go beyond parties' clarifications in an attempt to find a joint, subjective will.

In the modern world, jurisdictions continue to adjust their policies in contract law, directly or indirectly affecting contract interpretation. Given how mature modern contract laws have arguably become, through various specific means, changes in contract interpretation today are less dramatic and have less amplitude than those that Roman law manifests. Nevertheless, many of them are quite palpable. Upon more close and nuanced investigation, one may, for instance, observe developments evidencing a change from subjective to objective preferences in contract interpretation in Italy since the 196 os. $^{62}$ One can also observe some jurisdictions, such as Scotland, being one step away from clear statutory changes pertaining to contract interpretation, but ultimately choosing not to proceed with them. ${ }^{63}$ Among the most observable, one notes a recognition of the necessity to protect consumers and weaker parties, ${ }^{64}$ which relatively recently affected a broad range of jurisdictions and led

62 Luca G Radicati di Brozolo and Giacomo Marchisio, 'Trade Usages and Implied Terms in Italy' in Fabien Gelinas (ed), Trade Usages and Implied Terms in the Age of Arbitration (Oxford University Press 2016) 61.

63 In Scotland in 2011, the Law Commission performed a thorough investigation of contract interpretation suggesting to have statutory restatement expressing a clear support for a civil law approach to contract interpretation, particularly as evidenced by the DCFR - see The Scottish Law Commission, 'Review of Contract Law: Discussion Paper on Interpretation of Contract' (Discussion Paper No 147, February 2011) <www.scotlawcom. gov.uk/files/7412/9829/2343/dp147.pdf> accessed 25 June 2021. With Brexit, the reform plans aiming to make Scottish law closer to civil law traditions in the EU regarding contract interpretation will not go forward. In March 2018, the Scottish Law Commission observed in a Report that a much greater degree of consensus in the Scottish courts had emerged and that is why it refused to propose legislative reform or a statutory restatement of this matter - see Scottish Law Commission, 'Report on Review of Contract Law: Formation, Interpretation, Remedies for Breach, and Penalty Clauses' (scOT LAW COM No 252, SG/ 2018/34, March 2018) 69-96, available at <http://www.scotlawcom.gov.uk/files/1115/2222/ 5222/Report_on_Review_of_Contract_Law_-_Formation_Interpretation_Remedies_for_ Breach_and_Penalty_Clauses_Report_No_252.pdf> accessed 25June 2021.

64 Even though the level of intervention of state policy in between business parties' $\mathrm{B}_{2} \mathrm{~B}$ contracts is more restrictive, certain differentiations can take place in relation to small or individual entrepreneurs who are not formally consumers but who may apparently be seen as a weaker party. Blake D Morant argues on more differentiation towards small business as unequal parties in the USA - Blake D Morant, 'Contractual Interpretation in the Commercial Context' in Larry A DiMatteo and Martin Hogg (eds), Comparative Contract Law: British and American Perspectives (Oxford University Press 2016) 270-271. 
either to the introduction or the actualisation of contra proferentem rules in various contexts. ${ }^{65}$

Finally, while national laws set down fundamental rules on this question to deprive judges and arbitrators of untrammelled freedom, the nature of contract interpretation and its close intertwinement with the assessment of evidence and various interpretative choices brings certain discretionary elements into interpretative analysis. In permitting contextual evidence, some laws of the civil law tradition suggest that contract interpretation is a sequential or hierarchical analysis that stops at certain stages, if it achieves an unambiguous answer. ${ }^{66}$ Others leave the issue more to the adjudicators' discretion or have a

65 The idea of relying on contra proferentem has already gained widespread consensus in the EU at a regulatory level, with the protection of consumers. Contra proferentem has also been implemented by the UPICC and in the instruments attempting to harmonise European contract law more broadly than just in the field with consumers - the PECL, the DCFR and the CESL. In France, the amendments to the Civil Code introduced in Article 1190 a presumption of the interpretation against the creditor for the adhesion contract. Article 119o reads in English as follows: 'In case of any doubts, a [mutual] agreement shall be interpreted against the creditor and in favour of the debtor, and an adhesion contractagainst the party who offered it.' In Ukraine, for instance, the contra proferentem rule was not made an express part of the statutory regulation of contract interpretation under Ukrainian law in Article 213 and, accordingly, was not seen in jurisprudence relating to contract interpretation. Contra proferentem has appeared only very recently with the Decision of the Supreme Court of Ukraine on 18 April 2018. Somewhat earlier, contra proferentem penetrated into Russian law similarly through judicial guidance. Article 431 of the Civil Code of the Russian Federation did not contain a specific provision relating to contra proferentem. The principle was incorporated after the clarification of the Presidium of the High Commercial Code of the Russian Federation in 2014. Para.11 of the Decree of the Plenum of the High Commercial Code of the Russian Federation of 14 March 2014 No. 16 'On Contract Freedom and Its Limits' - Постановление Пленума Высшего Арбитражного Суда Российской Федерации №16 'О свободе договора и ее пределах' (14 марта 2014) <http://base.garant.ru/7062826o/> accessed 25 June 2021. On a comparative perspective of the contra proferentem rule, see Péter Cserne, 'Policy Considerations in Contract Interpretation: the Contra Proferentem Rule from a Comparative Law and Economics Perspective' (2007) 5 Hungarian Association for Law and Economics Working Paper $1<$ http://citeseerx.ist.psu.edu/viewdoc/download;jsessionid $=16418 D_{D B}{ }_{5} 3905$ C5577040BF61DACE1o?doi=10.1.1.624.5797\&rep=rep1\&type= pdf $>$ accessed 25 June 2021.

66 In Ukraine, according to the clarification of the Supreme Court, contract interpretation under Ukrainian law is three-tiered. The first stage is reading the words with their ordinary natural meaning, and if this does not lead to clarity, the second stage suggests looking at the contract as a whole. If this does not provide a clear answer, a third stage permits one to look at the broader context; see Decision of Supreme Court (Ukraine), Case No 753/11000/14-ц, 18 April 2018. The three stages follow from the content of Article 213 of the Civil Code of Ukraine, though Article 213 does not expressly refer to stages. 
somewhat blurred distinction. ${ }^{67}$ Unless the distinctions are clearly identified in a relevant regulation and faithfully observed in practice, their separation in scholarly writings is of little practical implication. When the stages are clearly identified, their observance may result in notable differences. ${ }^{68}$ Contextual evidence, for instance, may be permitted only if one discharges other attempts to ascertain the content of the contract, that in addition to a textual ascertaining, may require a reasonable construction of the third reasonable party. ${ }^{69}$ Even stages for contract interpretation do not however convert contract interpretation into a precise algorithm. Certain stages may be set, some preferences may be emphasised, or specific content may be excluded (for instance, pre-contractual negotiations and post-contractual conduct), but ultimately it is always up to the interpreter to structure an analysis and choose the relevant tools.

\subsection{Interpretative Approaches: Good Faith and Predictability}

The fundamental and widely reiterated distinction between civil and common law, in respect to contract interpretation, lies in the values that are ensured

67 For instance, contra proferentem, clearly used in Ukraine only as a last resort, receives a somewhat blurred application in Norwegian law, where the principle is used together with the application of other techniques - see Ole Lando and others (eds), Restatement of Nordic Contract Law (DJøF Publishing 2016) 167-195.

68 Article 431 of the Civil Code of the Russian Federation, establishing the primacy of literal interpretation to the exclusion of contextual evidence, has been criticised recently precisely because of its stages. Some scholars have suggested introducing a rebuttable presumption of a literal reading contained in Article 431 - seе Байрамкулов Алан, 'Толкование договора в российском и иностранном гражданском праве' (Диссертация, Институт законодательства и сравнительного правоведения при Правительстве Российской Федерации) 41-42. For other critical observations on the dominant literalism in the judicial application of Article 431 of the Civil Code of the Russian Federation, seе Наталья Вацлавовна Степанюк, Толкование гражданскоправового договора: проблемы теории и практики (НИЦ ИНФРА-М 2о13) 25 [Natalia Vatslavovna Stepanyuk, Interpretation of Civil Contracts: Problems of Theory and Practice (Scientific-Research Center INFRA-M 2013) 25].

69 The traditional approach to stages of contractual interpretation focus on the text first and then proceed to external sources and good faith and reasonableness, if applicable. Other authors rather idiosyncratically suggest a reverse interpretation hierarchy, starting from good faith and reasonableness and then moving on to the text. Social conceptions of contract law seem to dominate in this unconventional contractual interpretation sequence. In their view, this approach corresponds to the existing rules and doctrines of contractual interpretation, the parties' perception of their obligations under contracts and the social legitimisation of contractual values - see Eyal Zamir, 'The Inverted Hierarchy of Contract Interpretation and Supplementation' (1997) 97 Columbia Law Review 1710, 1710-1803. 
through interpretation. As discussed in the previous section, civil law traditionally emphasises a principle of good faith in contract interpretation, whereas common law emphasises predictability. Good faith implies that a contract has to be understood as having internal balance with reliability on the promises the parties have made. Ideas of reasonableness and fair dealing guide an interpreter in assessing and extracting the content of contractual provisions. ${ }^{70}$ Certain omissions are, accordingly, construed by implying what the parties might have meant but failed to expressly put into a contract. In addition to the construction of the implied terms of the contract, the principle can move an interpreter further, to reconstruction. Here, on the conceptual borderline of interpretation, the principle of good faith may catalyse far-reaching consequences by filling in omitted terms, downplaying unfair terms and correcting other contractual imbalances. Predictability in common law tradition prioritises the parties' agreement as reflected by the text of a contract. ${ }^{71}$ Driven by considerations of party autonomy and the sanctity of the contract, an interpreter has to accept that a contract properly and fully reflects the parties' undertakings. Any attempt to go beyond what the parties expressly agreed is not desirable under common law as it decreases the certainty of contracting.

Both principles are not necessarily mutually exclusive. On the one hand, the predictability of English contract law is frequently connected to fairness via certainty. On the other hand, adherence in the first place to what the parties agreed in the text of a contract may be viewed as a reflection of an interpretation exercised in good faith. The mutual exclusion of good faith and predictability, nevertheless, is not a phantom. It appears in marginal cases in which the application of one principle, at its critical capacity, excludes the results promoted by another. The most ascertainable examples of the collision between good faith and predictability emerge when good faith leads to the implication

70 Jacques H Herbots, 'Interpretation of Contracts', Elgar Encyclopedia of Comparative Law (Edward Elgar Publishing 2006) 343-344; Giuditta Cordero-Moss, 'Lectures on Comparative Law of Contracts' (2004) 166 Publications Series of the Institute of Private Law, University of Oslo 86-125; Bruno Zeller, 'Good Faith - Is it a Contractual Obligation?' (2003) 15(2) Bond Law Review 215, 215-239; Hugh Collins (ed), Standard Contract Terms in Europe: A Basis for and a Challenge to European Contract Law (Kluwer Law International 2008) 237-238.

71 Justice Steyn, 'The Role of Good Faith and Fair Dealing in Contract Law: A HairShirt Philosophy?' (1991) 6 The Denning Law Journal 131, 131-141; Jacques H Herbots, 'Interpretation of Contracts', Elgar Encyclopedia of Comparative Law (Edward Elgar Publishing 2006) 330-331; Giuditta Cordero-Moss, 'Lectures on Comparative Law of Contracts' (2004) 166 Publications Series of the Institute of Private Law, University of Oslo 86, 95-96. 
or supplementation of the terms or even trumps certain elements of the contractual text. It is precisely these marginal examples that civil lawyers praise for fairness and common lawyers criticise for unpredictability and uncertainty. ${ }^{72}$

The general distinction between the operation of good faith and predictability for contract interpretation does not exhaust all differences. Nor does it mean that each principle operates similarly in each jurisdiction in which they inform contract interpretation.

Regarding good faith in civil law tradition, it has a plurality of faces. While the Latin phrase bona fide may rightly be viewed as a common origin for good faith in European contract law, detailed studies demonstrate that the concept emerged and evolved individually in each state. ${ }^{73}$ It is, accordingly, not surprising that good faith may appear under various other names and in various, often undistinguishable, combinations of concepts: 'reasonableness, ${ }^{74}$ 'loyalty and fair dealing,75 'sincerity and faith"76 and 'fairness, good faith and

72 For critics of good faith by common lawyers see 'Why English Law Governs Most International Commercial Contracts' (QLTSchool, 12 September 2016) <www.qlts.com/ blog/english-law/why-english-law-governs-most-international-commercial-contracts> accessed 25 June 2021 (this article puts forward reasons why English law is most used for international business transactions). For an illustration of statements by civil lawyers in support of good faith see Catherine Valcke, 'Contractual Interpretation at Common Law and Civil Law: An Exercise in Comparative Legal Rhetoric' in Jason W Neyers, Richard Bronaugh and Stephen G A Pitel (eds), Exploring Contract Law (Hart Publishing 2009).

73 See the first four chapters in Good Faith in European Contract Law - Simon Whittaker and Reinhard Zimmermann, 'Good Faith in European Contract Law: Surveying the Legal Landscape' in Reinhard Zimmermann and Simon Whittaker (eds), Good Faith in European Contract Law (Cambridge University Press 200o) 7-62; Martin Josef Schermaier, 'Bona Fides in Roman Contract Law' in Reinhard Zimmermann and Simon Whittaker (eds), Good Faith in European Contract Law (Cambridge University Press 200o) 63-92; James Gordley, 'Good Faith in Contract Law in the Medieval Jus Commune' in Reinhard Zimmermann and Simon Whittaker (eds), Good Faith in European Contract Law (Cambridge University Press 2000) 93-117; Robert S Summers, 'The Conceptualisation of Good Faith in American Contract Law: A General Account' Reinhard Zimmermann and Simon Whittaker (eds), Good Faith in European Contract Law (Cambridge University Press 200o) 118-144; Reinhard Zimmermann, The Law of Obligations: Roman Foundations of the Civilian Tradition (reprint edn, Oxford University Press 1996) 622, 637 .

74 Section 307 of the German Civil Code; Article 6:248 of the Dutch Civil Code (referring also to fairness); Article 2 of the Civil Code of Byelorussia (the principle of fairness and reasonableness of the participants of civil legal relations).

75 In Nordic laws - Ole Lando and others (eds), Restatement of Nordic Contract Law (DJøF Publishing 2016) 181-183.

76 In addition to the principle of reasonableness, the German Civil Code establishes the principle of 'Treu und Glauben' in Section 242 as follows: 'An obligor has a duty to perform according to the requirements of good faith, taking customary practice into consideration.' 
reasonableness. ${ }^{77}$ Furthermore, good faith can sometimes be construed from the negative concept of bad faith. ${ }^{78}$ The mentioned terms are not necessarily full equivalents and may have somewhat different meanings depending on the context. Good faith can receive express statutory categorisation in various combinations, as an overarching principle of contract law, ${ }^{79}$ or as a more specific duty between the contracting parties during negotiations ${ }^{80}$ and in the course of contract performance, ${ }^{81}$ or directly as a criterion for interpretation. ${ }^{82}$ Even if the relevant law of the civil law tradition does not formally list good faith as a criterion for interpretation, this does not necessarily impede its role for such interpretation. On the other hand, the express listing of good faith as a criterion for contract interpretation does not automatically ensure its primary operation in such interpretation. Certain laws may attribute to good faith a much narrower function than might otherwise be contemplated from its express statutory formulation as a standard or a criterion for contract interpretation.

Below are some examples demonstrating that good faith operates somewhat differently in relation to contract interpretation across civil law traditions.

77 Article 6 of the Civil Code of the Russian Federation; Article 3 of the Civil Code of Ukraine.

78 Article 1 of the Civil Code of the Russian Federation; Section 815 of the German Civil Code.

79 The Civil Code of Ukraine, for instance, in Article 3 considers good faith as one of the main principles of civil law: '?. General foundations of the civil legislation include: 1) unacceptability of a self-willed intrusion into a private life of a human; 2) unacceptability of ownership deprivation except as established by the Constitution of Ukraine and the law; 3) freedom of agreement; 4) freedom of entrepreneurial activity; 5) judicial protectionof a civil right and interest; and 6) equity, good faith and reasonability'. See also Jacques $\mathrm{H}$ Herbots, 'Interpretation of Contracts', Elgar Encyclopedia of Comparative Law (Edward Elgar Publishing 2006) 343-345.

8o Section 311 of the German Civil Code; for Norwegian law - Giuditta Cordero-Moss, 'Lectures on Comparative Law of Contracts' (2004) 166 Publications Series of the Institute of Private Law, University of Oslo 128-129.

81 Section 242 of the German Civil Code (performance in good faith), for Norwegian law - Giuditta Cordero-Moss, 'Lectures on Comparative Law of Contracts' (2004) 166 Publications Series of the Institute of Private Law, University of Oslo 128-129.

82 Article 1198 of the Civil Code of Argentina (interpretation in good faith), Article 173 of the Civil Code of Greece (interpretation in conformity with the requirements of good faith taking into consideration business usage), Article 1366 of the Civil Code of Italy (interpretation in good faith), Article 20 of the Law on Contracts of Bulgaria (interpretation taking into account usages and good faith), Article 125 of the Chinese Law of Contracts (interpretation in conformity with usages and good faith), Section 157 of the German Civil Code (interpretation as required by good faith, taking customary practice into consideration); Article 1375 of the Civil Code of Italy (interpretation assessing the overall behaviour of the parties after contract conclusion), Article 1258 of the Civil Code of Spain (interpretation taking into account the acts at the time of performance and subsequently). 
The German Civil Code (Bürgerliches Gesetzbuch - BGB) lists good faith (in German 'Treu und Glauben' or literally "sincerity and faith") as a criterion for exercising contract interpretation (Section 157 of BGB: 'Contracts shall be interpreted according to the requirements of good faith, giving consideration to common usage.'). BGB also refers to good faith as a duty to perform an undertaking. (Section 242 of BG B says: 'The debtor is bound to effect performance according to the requirements of good faith, giving consideration to common usage.') The principle of good faith as a normative standard of interpretation has received pervasive reliance for a wide spectrum of interpretative tasks ranging from completion, concretisation and limitation to the correction of contracts. ${ }^{83}$ Judges have relied not only on Section 157, but mostly on Section 242 as a reflection of the dominant policy in contract relations. ${ }^{84}$ Prior to the appearance of Section 313, judges relied upon good faith as a corrective function in relation to unforeseen matters. ${ }^{85}$

In Italy, Article 1366 of the Civil Code, similarly to BGB, provides for an express statutory obligation to interpret contracts in good faith (in Italian 'Il contratto deve essere interpretato secondo buona fede' or in English 'The contract must be interpreted according to good faith'). Similar to Germany, good faith appears in other contexts, beyond interpretation, in the Italian Civil Code: in negotiations and contract drafting (Article 1337 of the Civil Code), in execution and performance of the contractual obligations (Article 1375 of the Civil Code), in a right not to perform because of the other party's failure (Article 146o of

83 The significant role of good faith, as part of the relevant normative context against which a contract has to be understood, is well captured by Helge Dedek (though the chapter focuses on trade usages and not contract interpretation as such): 'The idea that contract is never just a bare exchange of promises but is automatically and, by its very "nature," embedded in a framework of default rules, duties of good faith, and social obligations, is thus a civilian feature very strongly present in the German law of contract. Contracting is not only perceived as an activity subject to "disciplining" but also one that is intrinsically interwoven with a normative context.' [emphasis added] - see Helge Dedek, 'Not Merely Facts' in Fabien Gelinas (ed), Trade Usages and Implied Terms in the Age of Arbitration (Oxford University Press 2016) 92.

84 For the explanation of historical reasons for the active judicial application of Section 242 of the German Civil Code, see Giuditta Cordero-Moss, 'Lectures on Comparative Law of Contracts' (2004) 166 Publications Series of the Institute of Private Law, University of Oslo 123-124; Simon Whittaker and Reinhard Zimmermann, 'Good Faith in European Contract Law: Surveying the Legal Landscape' in Reinhard Zimmermann and Simon Whittaker (eds), Good Faith in European Contract Law (Cambridge University Press 2000) 18-32.

85 Ole Lando, 'Tradition versus Harmonization in the Recent Reforms of Contract Law' (2010) 3 Collected Courses of the Xiamen Academy of International Law 81, 100-101; Giuditta Cordero-Moss, International Commercial Contracts: Applicable Sources and Enforceability (Cambridge University Press 2014) 86. 
the Civil Code). Unlike in Germany, Article 1366 of the Italian Civil Code is less frequently invoked for contract interpretation - judges apply the provision on a residual basis when other rules of interpretation do not assist. ${ }^{86}$ And when good faith is invoked, it operates somewhat differently. The primary function of the provision is to ensure the objective approach towards contract interpretation. The provision is located precisely between subjective (Articles 136265 of the Italian Civil Code) and objective (Article 1367-71 of the Italian Civil Code) pillars of the interpretative rules in the Italian Civil Code. Effectively, good faith in Italian law does not control the language of the contract and is not capable of correcting clear language. ${ }^{87}$

In Ukraine, unlike in Germany and Italy, good faith is not included in the provision on methods of contract interpretation (Article 213 of the Civil Code). At the same time 'fairness, good faith and reasonableness' appear as a fundamental principle of the civil law of Ukraine (Article 3(6) of the Civil Code of Ukraine). Despite the promising status of a fundamental principle and the non-exhaustive list of rules for contract interpretation in Article 213 of the Civil Code of Ukraine, good faith, accordingly, has not emerged as a relevant normative standard for contract interpretation. ${ }^{88}$

It is also interesting to observe that in the Netherlands, in the absence of an express provision on the application of good faith for contract interpretation (to be precise in the absence of any statutory provision on contract interpretation) judges nevertheless rely on good faith when they have to ascertain the content of a contract. ${ }^{89}$ Good faith ('redelijkheid en billijkheid' or in English 'reasonableness and equity') under Dutch contract law, similarly to good faith in German law, is far-reaching. Relying on redelijkheid en billijkheid, an interpreter can correct and even supplement contractual provisions.

86 Silvia Ferreri, 'Chapter 5 Interpretation' in Luisa Antoniolli and Anna Veneziano (eds), Principles of European Contract Law and Italian Law - A Commentary (Kluwer Law International 2005) 258-259; Giuditta Cordero-Moss, 'Lectures on Comparative Law of Contracts' (2004) 166 Publications Series of the Institute of Private Law, University of Oslo 94-95.

87 Giuditta Cordero-Moss, 'Lectures on Comparative Law of Contracts' (2004) 166 Publications Series of the Institute of Private Law, University of Oslo 116.

88 Олександр Васильович Дзера та інші (ред.), Науково-практичний коментар Цивільного кодексу України, 1 т. (5-е вид., Юрінком Інтер 2013) 363-364 [Dzera O.V. and others (eds), Scientific and Practical Commentary to the Civil Code of Ukraine (5edn, 1 volume, Yurinkom Inter 2013, 301-312].

89 Martijn W Hesselink, 'The Concept of Good Faith' in Arthur Hartkamp and others (eds), Towards a European Civil Code (3rd fully rev. and exp. edn, Kluwer Law International 2004) 629; Sanne Taekema and others (eds), Understanding Dutch Law (Eleven International Publishing 2011) 266, 270-273. 
Similarly to differences in the application of good faith for contract interpretation in civil law tradition, the principle of predictability differs in its effect in common law traditions as well. The recent development under English law with Lord Hoffmann's widely cited five principles of interpretation, ${ }^{90}$ despite some views on introduced novelties, ${ }^{91}$ have not reversed the prevailing support towards predictability. The role of context - 'matrix of fact' - was not given a powerful changing role. According to Lewis, instead of representing 'a new departure in the interpretation of contracts', the five principles are 'restatement with differences of emphasis. ${ }^{92}$ The natural and ordinary meaning of the contractual text remains a default preference that can only be overturned/reversed under exceptional circumstances and with the application of other non-interpretative doctrines. In this respect, English law is rightly found to be significantly more predictable than the laws operating in the United States across a whole range of factors, including contract interpretation. According to Patrick Selim Atiyah, 'the English tradition of looking almost exclusively at the words of a document, and confining our attention to the general context of the document tends to lead to more predictable results, than the American tradition of allowing all sorts of other evidence to be produced.93 The laws of many states in the United States allow the admission of evidence external to the text, which may cause less predictability for the interpretative result. ${ }^{94}$ English law in turn remains most praised for safeguarding predictability, and this arguably enabled it to become one of the most used in international business transactions. ${ }^{95}$

Another distinction, intrinsically connected to the above and relatively easily palpable, between approaches in contract interpretation among various laws, relates to the admissibility of contextual evidence. Civil laws do not usually impose limitations on the scope of admissible evidence for the purpose of contract interpretation. On the contrary, many of them have express statutory

90 Lord Hoffmann summarised the principles in Investors Compensation Scheme v. West Bromwich Building Society [1998] 1 WLR 896 (19 June 1997).

91 Jacques H Herbots, 'Interpretation of Contracts' Elgar Encyclopedia of Comparative Law (Edward Elgar Publishing 2006) 331.

92 Kim Lewison, The Interpretation of Contracts (5th edn, Sweet \& Maxwell 2011) 3.

93 Patrick Selim Atiyah, 'Justice and Predictability in the Common Law' (1992) 15 University of New South Wales Law Journal 448, $45^{8}<$ www.austlii.edu.au/au/journals/UNSWLawJl/ 1992/19.pdf> accessed 25 June 2021.

94 Ahmet Cemil Yildirim, Interpretation of Contracts in Comparative and Uniform Law (Kluwer Law International 2019) 108-124.

95 See the results of the White \& Case and Queen Mary University survey of 2010 at the beginning of this chapter; see also Jonathan Morgan, Contract Law Minimalism: A Formalist Restatement of Commercial Contract Law (Cambridge University Press 2013) 171-217. 
provisions openly endorsing considerations of pre-contractual negotiations and parties' conduct. ${ }^{96}$ Common law countries traditionally control admissible evidence through the parol evidence rule that, in the presence of written text, excludes external evidence aiming to challenge or modify the parties' written agreement. ${ }^{97}$ The parol evidence rule has nothing to do with the traditional understanding of which evidence is admissible based on its relevance and reliability. Strictly speaking, the parol evidence rule is not a rule about evidence as such. The rule does not address evidence that lacks relevance or reliability; rather, it attacks a legal reasoning that attempts to overturn the meaning of a written contract. The evidentiary aspects discussed here accordingly are not of a procedural nature. They are of substantive character and primarily relate to the preferences given to written text through the exclusion of evidence external to the text. Being substantive in nature, the discussed rules retain importance and 'follow' a contract regardless of the procedural legal framework, whether it be court proceedings or international arbitration. ${ }^{98}$

96 For instance, Article 431 of the Civil Code of the Russian Federation, Article 213 of the Civil Code of Ukraine, Article 1362 of the Civil Code of Italy and Article 1282 of the Civil Code of Spain. At the same time, civil laws may impose some limitation on evidence if a mandatory written form for a contract was not observed. In Ukraine, for instance, when a statute requires a mandatory written form, one cannot rely on oral witness statements to challenge its existence or to challenge certain parts - Article 218 (1) of the Civil Code of Ukraine.

97 Describing a history of parol evidence rules at the beginning of the last century, John $\mathrm{H}$ Wigmore traces the origin of the rule back to the Middle Ages: 'Our primitive system knew it not. Towards the end of the middle ages does it come into and only in fairly modern times does it gain complete recognition.' - John H Wigmore, 'A Brief History of the Parol Evidence Rule' (1904) 4 Columbia Law Review 388, 338-355. On nuances in the application of the rules in various jurisdictions see Alberto Luis Zuppi, 'The Parol Evidence Rule: A Comparative Study of the Common Law, the Civil Law Tradition, and Lex Mercatoria' (2007) 35 Georgia Journal of International and Comparative Law 233, 233-276; Jacques H Herbots, 'Interpretation of Contracts' Elgar Encyclopedia of Comparative Law (Edward Elgar Publishing 2006) 336-339; for somewhat diverse views on the operation of the parol evidence rule see also Edward Allan Farnsworth, Contracts (2nd edn, Little, Brown and Company 1990) $55^{20-528 .}$

98 For instance, in a case of international commercial arbitration, a contract was governed by the substantive law of New York, which is known to include the parol evidence rule. Relying on the applicable substantive law, the sole arbitrator excluded witness evidence submitted by the respondent in the case. The respondent tried to have the award cancelled in the place of the seat, alleging that the non-acceptance of the witness evidence was a procedural defect which did not allow the respondent to fully present its case. However, the Svea Court of Appeal rejected the respondent's request and held that no violation of procedural law had taken place, as the parties had expressly agreed on the application of the law of New York while concluding the underlying agreement, and thus should have been aware of the exclusion of the parol evidence rule in the event of a 
The above description of differences between approaches towards contract interpretation under various laws, even over-simplified, is nevertheless helpful to better appreciate the role of national laws in contract interpretation. The juxtaposition between justice, value in civil laws jurisdictions, and predictability, endorsed in common laws, explains the operation of various conceptual solutions present in one legal tradition and absent in another. Limitations for contextual evidence, for instance, increase the predictability of reliance on the textual expression of a contract, whereas admission of pre-contractual negotiations and post-contractual conduct of the parties assists to ensure a fair result of contract interpretation. A more nuanced perspective on good faith and predictability reveals that neither principle operates identically across jurisdictions. The principles have their precise normative content that is formed historically in a given state and informs various distinctions of degree in contract interpretation. These differences again call for a thorough investigation of the applicable national law for contract interpretation.

\subsection{Limits of Subjective-Objective and Other Dichotomies}

The overview of the differences in approaches would not be complete if one were not to enter an area of various characteristics that are traditionally applied to mark distinctions across national laws: subjective-objective, fair-predictable, broad-literal, contextual-textual, etc. Because these characteristics penetrate so firmly into what we understand about differences in approaches to contract interpretation across various jurisdictions, it might be tempting to simply rely on some of them in a substitution to the actual investigation of the applicable regulation. An interpreter may, for instance, emphasise the joint intent of the parties to complement or override the textual expression of a contract, relying on the subjective approach of the applicable law to contract interpretation. Alternatively, an interpreter may emphasise that it is text as ascertained by a reasonable third party that has to take preference over any other consideration, relying on the objective preference to interpretation under applicable

dispute - see Mr. RR, Mr. VR and Ukio Banko Investiciné Grupé UAB v Rual Trade Limited, Svea Court of Appeal Case No. T 6238-10, Judgment of 24 February $2012<$ https://www.arbi tration.sccinstitute.com/Views/Pages $/$ GetFile. ashx?portalId $=89 \&$ cat $=95791 \&$ docId $=1767$ 474\&propId=1578> accessed 25 June 2021; Erik Mårild, 'Oral Representation of Evidence and the Application of the Parol Evidence Rule in International Arbitration' (2013) 24(2) American Review of International Arbitration 325. 
national law. For the reasons explained below, the described characteristics, however, cannot substitute proper investigation of the content of national law applicable to contract interpretation.

While being informative as to the existent differences across the legal spectrum, ${ }^{99}$ subjective-objective, fair-predictable, broad-literal, contextualtextual characteristics are merely the product of commentators. National laws do not explicitly use these terms in the wordings of the relevant parts on contract interpretation. The laws do not say that analysis must be 'subjective', but they may well say, 'the contract shall be interpreted according to the common intention of the parties.' ${ }^{100}$ Nor do the laws necessarily say that the interpretation must be 'contextual', but it may say that if it is impossible to establish the parties' true intentions from a literal reading of the contract, the purpose of the transaction, the content of previous negotiations, the established practice between the parties, usages, the parties' subsequent conduct, the text of standard contracts, and other circumstances which may have substantial significance should be considered. ${ }^{101}$ Judicial clarifications on contract interpretation, dominant for some jurisdictions, do not rely on these characteristics either. ${ }^{102}$ Subjective-objective, fair-predictable, broadliteral, contextual-textual are not interpretative rules, nor are they canons of interpretation. ${ }^{103}$ They are merely the dogmatised labels that reflect the doctrinal perspective on the peculiarities for contract interpretation under certain laws.

As the products of generalisation, these characteristics are not entirely explicit. Some of them may be on the verge of losing their sharpness or distinctiveness entirely. For instance, instead of being in polar opposition to each other, the subjective and objective approaches to contract interpretation appear rather as an accentuation of what is perceived to be dominant. From a more

99 The previous sections have used some of these dichotomies to mark the differences across the laws on contract interpretation, and some of the characteristics are also continuously relied upon throughout the work.

100 Article 213 (3) of the Civil Code of Ukraine provides, for instance, that ' $[i] n$ case the literal meaning of words and expressions as well as the meaning of terms generally accepted in the appropriate field of relations does not allow to establish the content of certain parts of the transaction, the content shall be established by comparing the relevant part of the transaction with the content of other parts thereof, with its general content and intentions of the parties'.

101 Article 213 (4) of the Civil Code of Ukraine.

102 See for instance, five principles summarised by Lord Hoffmann in Investors Compensation Scheme v West Bromwich Building Society, [1998] 1 WLR 896 (19 June 1997).

103 On the critical perspective over canons of interpretation, see the next chapter. 
nuanced perspective, one cannot but agree with James Spigelman's assessment, which helpfully captures the development of common law to become objective 'with a number of subjective exceptions' 104 and for civil law to be subjective 'with some objective exceptions. ${ }^{105}$ Indeed, it would currently be fairer to say that civil law jurisdictions do not perceive investigation of the joint intent of the parties in isolation from the objectivised confirmation, ${ }^{106}$ whereas common law jurisdictions permit one to look beyond the text alone to ensure that the parties' joint intent has been properly captured. ${ }^{107}$ At the same time, the precise degree of objective and subjective considerations much depend on thorough investigation of the regulation of the applicable national law. Similarly and as discussed before, there could be sensitive differences between various laws in what they precisely understand to be behind the role of good faith in contract interpretation or which extent of predictability is endorsed. Not only are these characteristics not entirely explicit, the commentators may mark what they emphasise somewhat differently, by applying the same or similar terms. In addressing 'objective' and 'subjective', 'textual' and 'contextual', etc., different authors may refer to 'approaches', 108 'theories'109 or 'dichotomies', 110 etc. Misunderstanding the meaning behind these categories has already led to the allegation of poorly-constructed arguments in scholarly writings. ${ }^{111}$ If

104 James Spigelman, 'The Centrality of Contractual Interpretation: A Comparative Perspective' (2015) 81 Arbitration 234, 249.

105 Ibid.

106 For instance, while Section 133 of the BGB provides that 'in interpreting a declaration of will one must seek out what was really intended and not adhere to the literal meaning of the words used', Section 157 of the BG B enables one at the same time to rely on fair dealing and normal practice, which is an objectivised area external to the subjective intent. Similarly, the Civil Code of France, while endorsing the necessity to investigate the common intent of the parties, contains an objectivised standard of a reasonable person in Article 1188.

107 The restatement of rules of contract interpretation by Lord Hoffmann, discussed earlier, confirms more openness towards the parties' intent.

108 Gerard McMeel and Hans Christoph Grigoleit refer to three approaches 'three related spectra: certainty and justice; subjective and objective; textual and contextual' - Gerard McMeel and Hans Christoph Grigoleit, 'Interpretation of Contracts' in Gerhard Dannemann and Stefan Vogenauer (eds), The Common European Sales Law in Context: Interactions with English and German Law (Oxford University Press 2013) 341.

109 Steven J Burton refers to literalism, objectivism and subjectivism in Steven J Burton, Elements of Contract Interpretation (Oxford University Press 2009) 17-34.

110 Larry A DiMatteo, 'False Dichotomies in Commercial Contract Interpretation' (2012) 11(1) Journal of International Trade Law and Policy 27, 39.

111 See, for instance, Steven Burton pointing to a somewhat different understanding of literalism by scholars in law and economics in comparison with a doctrinal perception of literalism dominant for a particular jurisdiction - Steven J Burton, Elements of Contract Interpretation (Oxford University Press 20o9) 36-37. Further, Giuditta Cordero-Moss 
relied upon in isolation from the relevant normative regulation, said characteristics may mislead, when what is precisely meant by them is not properly explained.

The limits of dogmatised labels can be appreciated further with historical examples. Approaching the practice of contract interpretation in Roman law from nowadays, one may indeed perceive it to be unduly formalistic at one period of time and unduly subjective at another. Reinhard Zimmerman, warns against this understanding. At that time, lawyers did instrumentalise the subjective and objective categories and perceived contract law in its entirety 'without isolating their individual components or dogmatising the objective or subjective elements contained in them.' ${ }^{112}$ For this reason, applying an objective or subjective approach, no matter how one understands 'objective' or 'subjective', would not work for the proper application of Roman law. Reliance on these categories in disengagement from applicable law in existence at that time would evidence a temporal bias. Reliance on these categories in disengagement from applicable law nowadays instead of a temporal bias could open a door to subjective biases. An interpreter may rely upon dogmatised labels to imitate certain normative justifications, essentially hiding the subjective element of what one perceives as being subjective or objective, textual or contextual, fair or predictable, etc. As it would not be proper to put 'the past into the straitjacket of contemporary conceptions', ${ }^{113}$ it would not work to reduce all contract regulation on contract interpretation to several dichotomies.

Thus, the commonly referred labels cannot guarantee that interpretation properly reflects how contract interpretation shall be exercised under applicable national law. Accordingly, they cannot turn into a substitute to a thorough investigation of contract interpretation under proper national law. At the same time, subjective-objective, fair-predictable, textual-contextual, etc., are all helpful

illustrates differences in understanding 'objective' under English and Norwegian contract doctrine - Giuditta Cordero-Moss, 'Ulike Trekk ved Norsk og Engelsk Kontraktsrett og Deres Betydning for Kontraktens Virkninger - Noen Komparativrettslige Betraktninger, (2016) 51 Jussens venner 276, 276-289. At the same time, Jacques H Herbots suggests that the role of the subjective-objective divide diminished in its role in scholarly writings: 'In our days this different approach no longer gives rise to hefty academic discussions, but one continues to find the distinct accentuation in the various legal systems of the world' - see Jacques H Herbots, 'Interpretation of Contracts' Elgar Encyclopedia of Comparative Law (Edward Elgar Publishing 2006) 329.

112 Reinhard Zimmermann, The Law of Obligations: Roman Foundations of the Civilian Tradition (reprint edn, Oxford University Press 1996) 626.

113 Ibid. 
to understand some peculiarities of contract interpretation under national law as they can properly accentuate certain approaches. They may also appear as useful tools for describing interpretative preferences and enhancing contractual drafting and thorough decision-making processes.

\subsection{Conclusion}

Understanding that national laws govern contract interpretation differently follows from appreciation of contract interpretation as a complex phenomenon deeply integrated into relevant national law. We know nowadays that laws of various jurisdictions may apply different non-interpretative doctrines and achieve similar results, that can be wrongly viewed as a result of interpretation. Conversely, different laws may apply similar interpretative rules and doctrines but reach different conclusions precisely because of the influence of other non-interpretative doctrines. In other words, similarities in results do not ensure that the laws approach contract interpretation uniformly, nor do different results signal a different regulation of contract interpretation. This deep appreciation of contract interpretation as a distinct set of regulations, on the one hand, and as an integral part of the relevant national law, on the other hand, informs this research.

If traced distinctions in contract interpretation are summarised in a sentence, one can say that the national laws differ in the fundamental overarching approaches towards contract interpretation favouring either good faith or predictability. Again, the juxtaposition of good faith and predictability, while informative, does not discharge all other differences though. Even within a group of laws supporting good faith as a fundamental interpretative criterion, there could be a number of nuances and differences in the precise reach of good faith that would make each approach, if not distinct, then at least peculiar. Similarly, the adherence to predictability is not absolute and may be modified by various exceptions depending on jurisdiction. Also, the role of an interpreter is not equally aligned across various laws. An interpreter may be limited by the text of the contract or enjoy the right to imply terms or even fill the omitted terms. That terms are clear may exclude interpretation in some jurisdictions or be the result of interpretation in others. Other more detailed regulatory aspects of contract interpretation, including sources for contract interpretation, interpretative stages, the admissibility of some forms of evidence and non-admissibility of others, etc. can be equally significant for tracing distinctions and similarities. Above all, national law as a background law 
featuring specific regulation in the fields of concession, privatisation, broadcasting, construction etc. may turn critical for understanding the contractual undertakings of the parties. Despite their high level of generalisation and the omission of more nuanced differences, the packing of the results of comparisons into either of the two groups is still informative for the main proposition of this chapter, namely that national laws govern contract interpretation differently.

Just as national law is not frozen, so may contract interpretation also evolve. Various reforms of contractual regulation directly or indirectly affect contract interpretation. The accentuation of certain preferences, or more substantial changes, regularly finds its way into national laws that, depending on jurisdiction, take the form of judiciary guidance or amendments of statutory provisions. One can discern movement from formalism to objectivism or back to more formalism with numerous more subtle developments. Viewed from this perspective, contract interpretation's uniqueness appears to be the live product of social and historical development of the national law of a particular state. It is not static, nor universal, but is evolving and reflective of the development of national law.

In addition to comparative studies, international commercial arbitration gives further thoughts on the significance of national law for contract interpretation. If in a national context, before the state courts, there are fewer possibilities to appreciate the differences in contract interpretation among various laws, but international commercial arbitration gives one this opportunity. Laws applicable to contract interpretation and laws known to arbitrators are frequently not the same. This leads to the temptation, for arbitrators, either to disengage contracts from applicable national law and construct contracts commercially or reasonably, or to rely consciously or unconsciously on the interpretative preferences of their home jurisdictions, regardless of the fact that those laws may be not applicable to the contract at hand. Both these reoccurring temptations demand a greater awareness. Firstly, contract interpretation disengaged from applicable national law has triggered critics and led to a growing consensus among scholars and practitioners on the role of national law for contract interpretation. Secondly, arbitrators' biases, originating from the preferences towards contract interpretation in their home jurisdictions, have gained deeper attention beyond simple anecdotal illustrations. And while an idea of transnational rules on contract interpretation might still be attractive, the growing trend appears to appreciate predictability in the tribunals' reasoning achievable through application of the national law governing contracts. 
This chapter's conclusion that national laws do not regulate contract interpretation uniformly leads to other questions, such as whether international law may be viewed as capable of substituting national law in the regulation of contract interpretation. This question will be addressed in the chapter that follows. 